\title{
Anatomy of a subtropical intrathermocline eddy
}

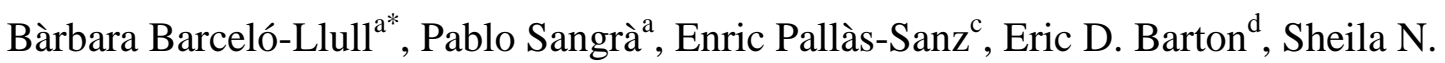
Estrada-Allis $^{\mathrm{c}}$, Antonio Martínez-Marrero ${ }^{\mathrm{a}}$, Borja Aguiar-González ${ }^{\mathrm{e}}$, Diana Grisolía ${ }^{\mathrm{a}}$, Carmen

Gordo $^{\mathrm{a}}$, Ángel Rodríguez-Santana ${ }^{\mathrm{b}}$, Ángeles Marrero-Díaz ${ }^{\mathrm{b}}$, Javier Arístegui $^{\mathrm{a}}$

a Instituto de Oceanografía y Cambio Global, IOCAG, Universidad de Las Palmas de Gran Canaria, ULPGC, Gran Canaria, Spain

${ }^{\mathrm{b}}$ Departamento de Física, Universidad de Las Palmas de Gran Canaria, ULPGC, Gran Canaria, Spain

${ }^{c}$ Departamento de Oceanografía Física, CICESE, Ensenada, México

d IIM, CSIC, Eduardo Cabello 6, Vigo 36208, Spain

${ }^{\mathrm{e}}$ NIOZ Royal Netherlands Institute for Sea Research, Department of Ocean Systems

Sciences and Utrecht University, P.O. Box 59, 1790 AB Den Burg, Texel, the Netherlands

*Corresponding author: Facultad de Ciencias del Mar, Universidad de Las Palmas de Gran Canaria, Campus Universitario de Tafira, Las Palmas de Gran Canaria, 35017 Las Palmas, Spain.b.barcelo.llull@gmail.com

\begin{abstract}
An interdisciplinary survey of a subtropical intrathermocline eddy was conducted within the Canary Eddy Corridor in September 2014. The anatomy of the eddy is investigated using near submesoscale fine resolution two-dimensional data and coarser resolution threedimensional data. The eddy was four months old, with a vertical extension of $500 \mathrm{~m}$ and 46 $\mathrm{km}$ radius. It may be viewed as a propagating negative anomaly of potential vorticity $(\mathrm{PV})$, 95\% below ambient PV. We observed two cores of low PV, one in the upper layers centered at $85 \mathrm{~m}$, and another broader anomaly located between $175 \mathrm{~m}$ and the maximum sampled depth in the three-dimensional dataset $(325 \mathrm{~m})$. The upper core was where the maximum absolute values of normalized relative vorticity (or Rossby number), $|\mathrm{Ro}|=0.6$, and azimuthal velocity, $U=0.5 \mathrm{~m} \mathrm{~s}^{-1}$, were reached and was defined as the eddy dynamical core. The typical biconvex isopleth shape for intrathermocline eddies induces a decrease of static stability, which causes the low PV of the upper core. The deeper low PV core was related to the occurrence of a pycnostad layer of subtropical mode water that was embedded within the eddy. The eddy core, of $30 \mathrm{~km}$ radius, was in solid body rotation with period of 4 days. It was encircled by a thin outer ring that was rotating more slowly. The kinetic energy (KE) content
\end{abstract}




\section{ACCEPTED MANUSCRIPT}

exceeded that of available potential energy (APE), KE/APE $=1.58$; this was associated with a low aspect ratio and a relatively intense rate of spin as indicated by the relatively high value of Ro. Inferred available heat and salt content anomalies were AHA $=2.9 \times 10^{18} \mathrm{~J}$ and ASA $=$ $14.3 \times 10^{10} \mathrm{~kg}$, respectively. The eddy AHA and ASA contents per unit volume largely exceed those corresponding to Pacific Ocean intrathermocline eddies. This suggests that intrathermocline eddies may play a significant role in the zonal conduit of heat and salt along the Canary Eddy Corridor.

Keywords

intrathermocline eddy, mesoscale eddy, potential vorticity, Canary Eddy Corridor

\section{Introduction}

Intrathermocline eddies are a particular type of subsurface intensified anticyclonic eddy (Dugan et al., 1982; McWilliams, 1985; Kostianoy and Belkin, 1989). Their imprint in hydrographic fields is characterized by dome-shaped isopleths in the upper layers and a bowlshape in the lower layers, sometimes with a homogeneous pycnostad layer embedded within. As a consequence of the decrease of static stability at the eddy core, a large negative anomaly of potential vorticity develops (Gordon et al., 2002; Pidcock et al., 2013). Intrathermocline eddies are relatively frequent and, in some regions such as in the eastern boundary upwelling systems (EBUS), they may represent 30-55\% of the anticyclonic eddy population (Pegliasco et al., 2015).

There is a great variety of intrathermocline eddies with different origins. Those generated by the poleward undercurrents in the EBUS (Hormazabal et al., 2013; Pelland et al., 2013; Pegliasco et al., 2015) have a typical radius between $20 \mathrm{~km}$ (California EBUS) and $60 \mathrm{~km}$ (Peru-Chile EBUS) and a vertical extent of ca. $500 \mathrm{~m}$. They generally do not contain a homogeneous core (or pycnostad layer) but they are characterized by a minimum in oxygen (Hormazabal et al., 2013; Stramma et al., 2013). A particular type of these eddies are swoddies, or Slope Water Oceanic eddies, generated by destabilization of the highly baroclinic poleward slope current off the Iberian Peninsula, also known as Iberian Poleward Current, in winter (Pingree and Le Cann, 1992a, b; García-Soto et al., 2002; Sánchez and Gil, 2004; Carton et al., 2013). In summer, the seasonal thermocline is restored capping the feature (Sánchez and Gil, 2004). They usually have radius of 40-60 km, contain a homogeneous core of slope water ( $20-30 \mathrm{~km}$ radius and $\sim 200 \mathrm{~m}$ thickness) with maximum azimuthal velocities at $100 \mathrm{~m}$ depth, and drift mostly westwards at $2 \mathrm{~cm} \mathrm{~s}^{-1}$. On the other 


\section{ACCEPTED MANUSCRIPT}

hand, Mediterranean water eddies, or meddies, generated from instabilities of the Mediterranean Undercurrent, have also been observed in the Iberian and Canary Basins (Hebert et al., 1990; Schultz Tokos and Rossby, 1991; Shapiro et al., 1995, Carton et al., 2010; L'Hégaret et al., 2014, Bashmachnikov et al., 2015). They are salty and warm deep lenses usually centered at $1000 \mathrm{~m}$ depth that may drift, mainly southwestwards, during 1-3 years. They usually have 20-75 $\mathrm{km}$ radius, 500-1000 m thickness and maximum azimuthal velocities of $0.2-0.5 \mathrm{~m} \mathrm{~s}^{-1}$. In the Subarctic region large intrathermocline eddies of $60 \mathrm{~km}$ radius and ca. $1300 \mathrm{~m}$ vertical extent have been observed that have deep cores $(600 \mathrm{~m})$ of homogeneous water (Martin and Richards, 2001; Pidcock et al., 2013). In contrast, those described for the Japan Sea or for the Southern Indian Ocean regions are shallow flat homogeneous water lenses with $50 \mathrm{~km}$ radius, vertical extents of only $100 \mathrm{~m}$ to $150 \mathrm{~m}$, and oxygen-rich cores (Gordon et al., 2002; Hogan and Hurlburt, 2006; Nauw et al., 2006). In the

subtropical northeast Atlantic Ocean, Pingree (1996) gave the first description of an intrathermocline eddy inside the Canary Eddy Corridor (Sangrà et al., 2009). The eddy had a radius of $60 \mathrm{~km}$ and a vertical extent of $600 \mathrm{~m}$. It was 18 months old at the time of the eddy sampling and was located ca. $1800 \mathrm{~km}$ west of the Canary Islands. Recently, Caldeira et al. (2014) sampled an intrathermocline eddy generated in the lee of Madeira Island as an ocean response to wind-forcing. The sampled eddy had a radius of $26 \mathrm{~km}$ and it was surveyed at the generation region.

Amongst the population of intrathermocline eddies there is a particular type whose core is composed of homogeneous oxygen-rich mode water (Oka, 2009; Caldeira et al., 2014). Mode water is the name given to a layer of nearly vertically homogeneous water found over a relatively large geographical area, and which is identifiable through the contrast in stratification with the pycnocline waters (Hanawa and Talley, 2001). Mode waters have their origins in the deep mixed layers formed by winter convection. It has been observed recently that intrathermocline eddies originated in western boundary systems play a crucial role in mode water transport and subduction into the main thermocline (Xu et al., 2016).

Apart from those eddies that are locally generated by poleward undercurrents (eg. Pelland et al., 2013; Pegliasco et al., 2015), or in the Subarctic region (eg. Pidcock et al., 2013), the origin of intrathermocline eddies is still under discussion. Thomas (2008) proposed that a source for intrathermocline eddies is the reduction of potential vorticity in frontal regions with winds blowing in the direction of the frontal jet. As indicated above, 


\section{ACCEPTED MANUSCRIPT}

intrathermocline eddy cores contain negative anomalies of potential vorticity. Wind-front interactions subduct low potential vorticity waters that are the source for intrathermocline eddies. Hogan and Hurlburt (2006) investigated numerically the origin of intrathermocline eddies in the Japan Sea. They conclude that there are three different mechanisms that affect the formation of intrathermocline eddies: 1) advection of stratified water that caps a preexisting anticyclone; 2) restratification of the upper layers in a pre-existing anticyclone due to solar heating and; 3) frontal convergence and subduction of winter surface mixed layer water. This latter mechanism has also been proposed for Southern Indian Ocean intrathermocline eddies (Nauw et al., 2006). Recently McGillicuddy (2015) proposed eddy-wind interaction (Martin and Richards, 2001; McGillicuddy et al., 2007) as a new generation mechanism of intrathermocline eddies, which would drive an upwelling strong enough to induce the doming of the near surface isopycnals of an anticyclonic eddy.

A distinctive feature of the Canary EBUS is the presence of the Canary Island archipelago that acts as barrier to the prevailing currents and winds and is thus a continuous source for mesoscale eddy generation (Arístegui et al., 1994; Barton et al., 2000; Jiménez, et al., 2008; Piedeleu et al., 2009; Sangrà et al., 2005, 2007, 2009). These eddies contribute to the Canary Eddy Corridor which is the main pathway for long-lived eddies in the subtropical northeast Atlantic, making it a suitable region for the observation of mesoscale eddies (Sangrà et al., 2009). Long-lived anticyclonic eddies are much more frequent than cyclones. With the aim to study the oceanic vertical pump (Klein and Lapeyre, 2009) inside an anticyclonic eddy, we conducted an interdisciplinary survey of an intrathermocline eddy inside the Canary Eddy Corridor in September 2014. As detailed in Section 2, we intensively sampled the eddy obtaining fine resolution two-dimensional (2D) data and coarser resolution three-dimensional (3D) data. To the best of our knowledge, such intensive sampling has not been performed in previous studies of intrathermocline eddies. In this study we describe in detail the anatomy of an intrathermocline eddy. This paper will provide the hydrographic background to a series of other studies, currently in preparation, based on the survey data set, such as those dealing with inference of ageostrophic secondary circulation or with the impacts of the eddy on biogeochemical fluxes and plankton community structure and activity.

\section{The PUMP survey}

For the five months before the eddy survey, conducted aboard the R/V Hespérides, we monitored on a daily basis the signature of anticyclonic eddies generated by the Canary 


\section{ACCEPTED MANUSCRIPT}

Islands in the sea level anomaly (SLA) field. Daily SLA maps (Capet et al., 2014) were obtained from gridded data provided by AVISO (http://www.aviso.altimetry.fr). In May 2014 an anticyclone was shed by the island of Tenerife. The eddy was tracked until September 2014, when it was $550 \mathrm{~km}$ to the southwest (Figure 1). As we knew its origin and its signature in the SLA field was robust, we selected this 4 months old eddy to be the target for our study. We named the eddy "PUMP" as it was surveyed in the framework of the PUMP (Study of the Vertical Oceanic Pump in mesoscale eddies) project.

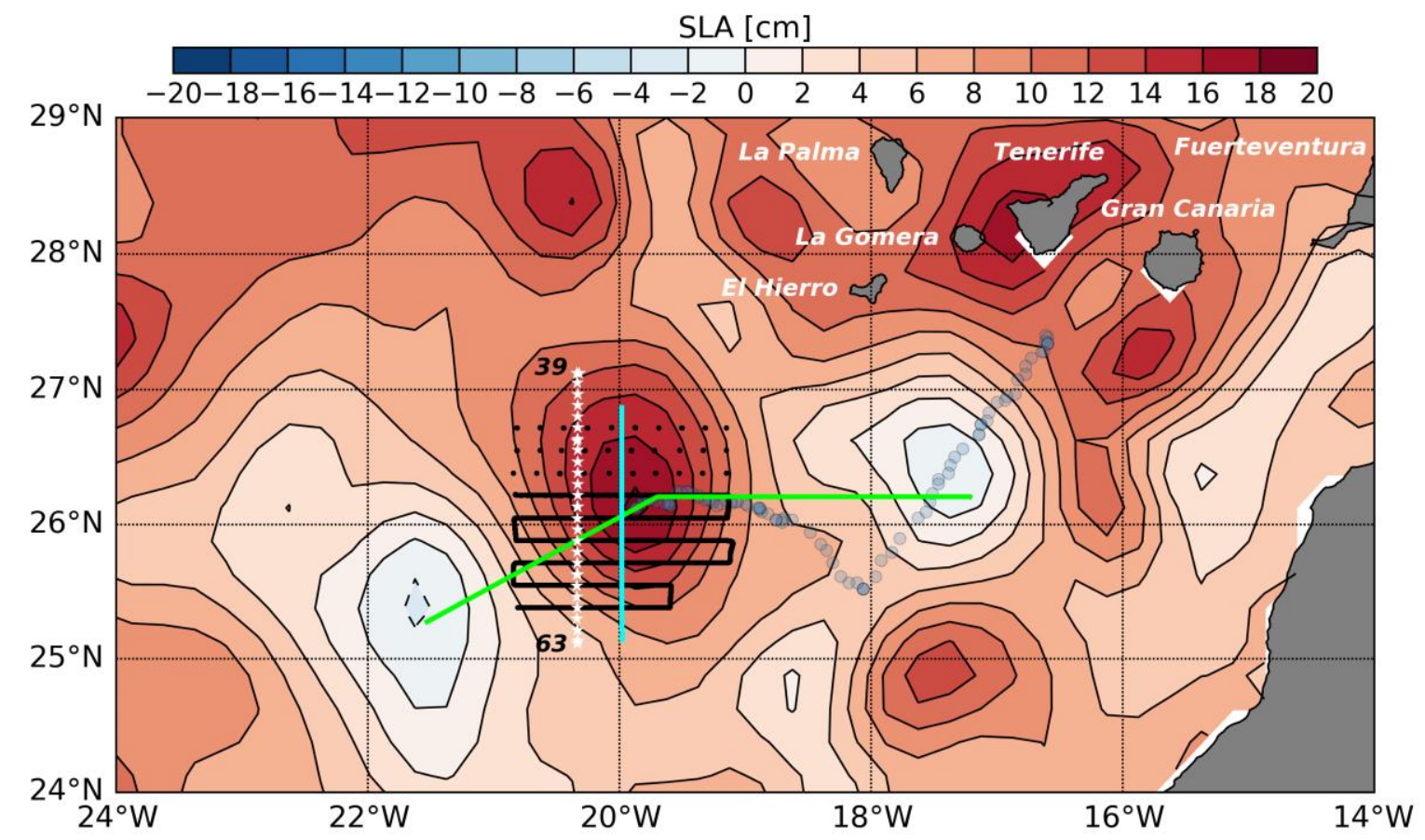

Figure 1: Map of the Eddy Canary Corridor. Colors show sea level anomaly (SLA) from AVISO on 3 September 2014. Green and cyan lines represent Phase 1 of the PUMP cruise, taken to locate the eddy center. Black lines and dots mark the grid of the 3D eddy sample with SeaSoar continuous tows and rosette system discrete casts, respectively (Phase 2). White stars indicate high-resolution CTD stations in Le Tourmalet section (Phase 3). The trajectory of the eddy center from its formation to the beginning of the cruise is depicted by blue dots (the time interval between dots is 1 day). The eddy translated westwards with a speed of $4 \mathrm{~km}$ $\mathrm{d}^{-1}\left(0.046 \mathrm{~m} \mathrm{~s}^{-1}\right)$ during the eddy sampling.

The eddy survey was organized into 3 phases (Figure 1). Guided by the eddy signal in the SLA field, we first crossed the eddy with two transects (Figure 1, green and cyan lines) sampled with continuous tows of a Conductivity Temperature Depth (CTD) probe on an undulating vehicle (SeaSoar) during the days 3-5 September 2014. The objective was to locate the eddy center and to make a first estimate of its radius and depth. Next, in order to 


\section{ACCEPTED MANUSCRIPT}

obtain 3D fields of hydrographic and dynamical variables, we sampled a grid centered on the eddy center. The grid consisted of 6 SeaSoar (Figure 1, black lines) and 3 rosette (the SeaSoar CTD was attached to a rosette system after failure of the SeaSoar; Figure 1, black dots) zonal transects of length $166.68 \mathrm{~km}$. Transects were $18.52 \mathrm{~km}$ apart, as were the rosette stations. The resulting 3D grid, combining rosette casts at discrete stations with SeaSoar tows, had a size of $166.68 \times 166.68 \mathrm{~km}$ with $18.52 \times 18.52 \mathrm{~km}$ resolution. In most profiles, the SeaSoar measurements extend from $10 \mathrm{~m}$ down to $325 \mathrm{~m}$. Rosette casts were made to a nominal depth of $400 \mathrm{~m}$. The 3D survey was accomplished in five days (6-11 September 2014). In the third and final phase, we crossed the eddy center meridionally with a $222.24 \mathrm{~km}$ transect (that we named Le Tourmalet) consisted of 24 CTD stations spaced approximately $9.26 \mathrm{~km}$ apart (Figure 1, white stars). In addition, microstructure measurements and water samples for biogeochemical studies were taken along this transect. CTD casts were made to a nominal depth of $1000 \mathrm{~m}$ and the transect was sampled over 3 days (12-15 September).

The undulating vehicle we used was a SeaSoar Mk II with an onboard CTD SB911+ additionally equipped with a Seapoint Chlorophyll Fluorometer, dual SBE43 oxygen sensors, and a Seapoint Turbidity Meter. On average, the profiles were separated by $4 \mathrm{~km}$ with an effective vertical resolution of $72 \mathrm{~cm}$. Rosette casts were also made using the CTD SB911+ instrument additionally equipped with a Seapoint Chlorophyll Fluorometer, dual SBE43 oxygen sensors, Wetlabs C-Star Transmissometer $(25 \mathrm{~cm} 660 \mathrm{~nm})$, Seapoint Turbidity Meter, and Biospherical Remote Photoradiometer sensors attached to the rosette system of 24 oceanographic 121 Niskin bottles. Raw data files were processed with Sea-Bird SEASOFT software (http://www.seabird.com/software/softrev.htm) and vertically averaged into $1 \mathrm{~m}$ bins. We use the TEOS-10 algorithms to calculate absolute salinity, $\mathrm{S}_{\mathrm{A}}$, and conservative temperature, $\Theta$, and all derived variables (Feistel, 2003, 2008).

Current velocities were measured continuously in all three phases using a hullmounted $75 \mathrm{kHz}$ RDI Acoustic Doppler Current Profiler (ADCP). The ADCP provided raw data with 5-min ensembles from the surface to $\sim 800 \mathrm{~m}$ and a bin size of $8 \mathrm{~m}$. The raw data were quality controlled, corrected for heading misalignment and edited with the Common Oceanographic Data Access System (CODAS, Firing et al., 1995). On average, the processed profiles provide good quality data from 30 to $700 \mathrm{~m}$ depth. 


\section{ACCEPTED MANUSCRIPT}

\section{PUMP eddy signature}

The purpose of the SeaSoar transects on Phase 1 (Figure 1, green and cyan lines) was to sample the in situ signal of the SLA tracked eddy seen in Figure 1, in the context of its immediate environment. Figure 2 shows a vertical section of the potential density anomaly, $\sigma_{\Theta}$, along the east-west transect sampled on Phase 1 (Figure 1, green line) superposed on the cross-transect velocity as obtained from the ship-mounted ADCP. At $280 \mathrm{~km}$ distance the upper seasonal pycnocline is dome-shaped, whereas the permanent pycnocline located below is bowl-shaped leading to a biconvex shape of the isopycnals. Furthermore, between the depths of the $26.5 \mathrm{~kg} \mathrm{~m}^{-3}$ and $26.6 \mathrm{~kg} \mathrm{~m}^{-3}$ isopycnals a layer of almost uniform potential density anomaly typical of Madeira Mode Water is evident (Käse et al., 1985; Siedler et al., 1987; Weller et al., 2004). The eddy shows a deep intensified anticyclonic circulation with maximum (minimum) velocity values of $0.38(-0.35) \mathrm{m} \mathrm{s}^{-1}$ at 81 (97) $\mathrm{m}$. This subsurface intensified anticyclonic flow implies a vertical shear that is consistent with the biconvex isopycnal shape through thermal wind balance. Above (below) this subsurface speed maximum a negative (positive) vertical shear of the horizontal velocity will adjust with a negative (positive) radial gradient of density leading to shoaling (deepening) of the isopycnals. Hereinafter we will sometimes refer to the domed upper layers as the eddy cap. As evident in Figure 1, this transect also partially crossed two cyclonic eddies located one at each end of the transect. The combined vertical section of $\sigma_{\Theta}$ and cross-transect ADCP velocity clearly shows the signal of these eddies through the shoaling of the isopycnals and a cyclonic circulation (Figure 2). Notice, however, that both structures are well separated from the PUMP eddy, so that the intrathermocline PUMP eddy may be considered as an isolated structure. 


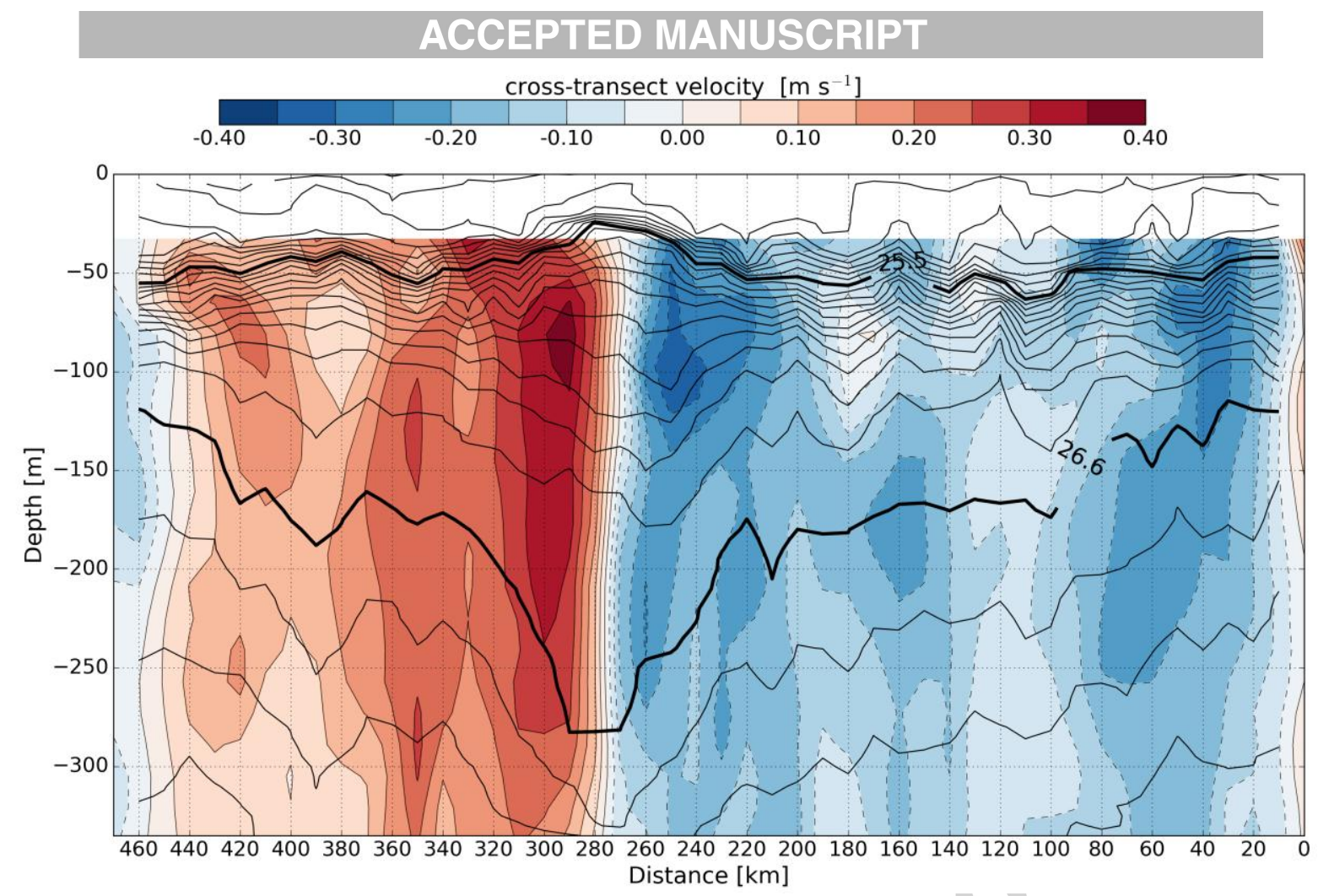

Figure 2: Vertical section along the east-west transect in Phase 1 (3-5 September 2014; Figure 1, green line) of the cross-transect ADCP velocity with superimposed contours of potential density anomaly, $\sigma_{\Theta}$. Thick contours are $\sigma_{\Theta}=25.5 \mathrm{~kg} \mathrm{~m}^{-3}$ and $\sigma_{\Theta}=26.6 \mathrm{~kg} \mathrm{~m}^{-3}$ (contour interval is $0.1 \mathrm{~kg} \mathrm{~m}^{-3}$ ).

To describe the vertical structure of the PUMP eddy we have selected the Le Tourmalet transect (Figure 1, white stars) as it crossed the eddy center and reached $1000 \mathrm{~m}$ depth. Figure 3 shows a combined vertical section of $\sigma_{\Theta}$ and cross-transect (zonal) ADCP velocity along Le Tourmalet transect. The PUMP eddy is centered at station 51, and its signal is noticeable in both fields to at least ca. $500 \mathrm{~m}$ depth. Property anomalies (Figure 4a-c) were calculated by subtracting at each depth the corresponding average of the reference stations $(39,40$ and 62,63$)$ located at both ends of the transect. A vertical section of the $\sigma_{\Theta}$ anomaly (Figure 4a) indicates that the eddy extends between stations 46 and 56, thus having a $92 \mathrm{~km}$ diameter. The corresponding eddy radius, $46 \mathrm{~km}$, is of the order of the climatological first baroclinic Rossby radius of deformation for the region (Chelton et al., 1998). 


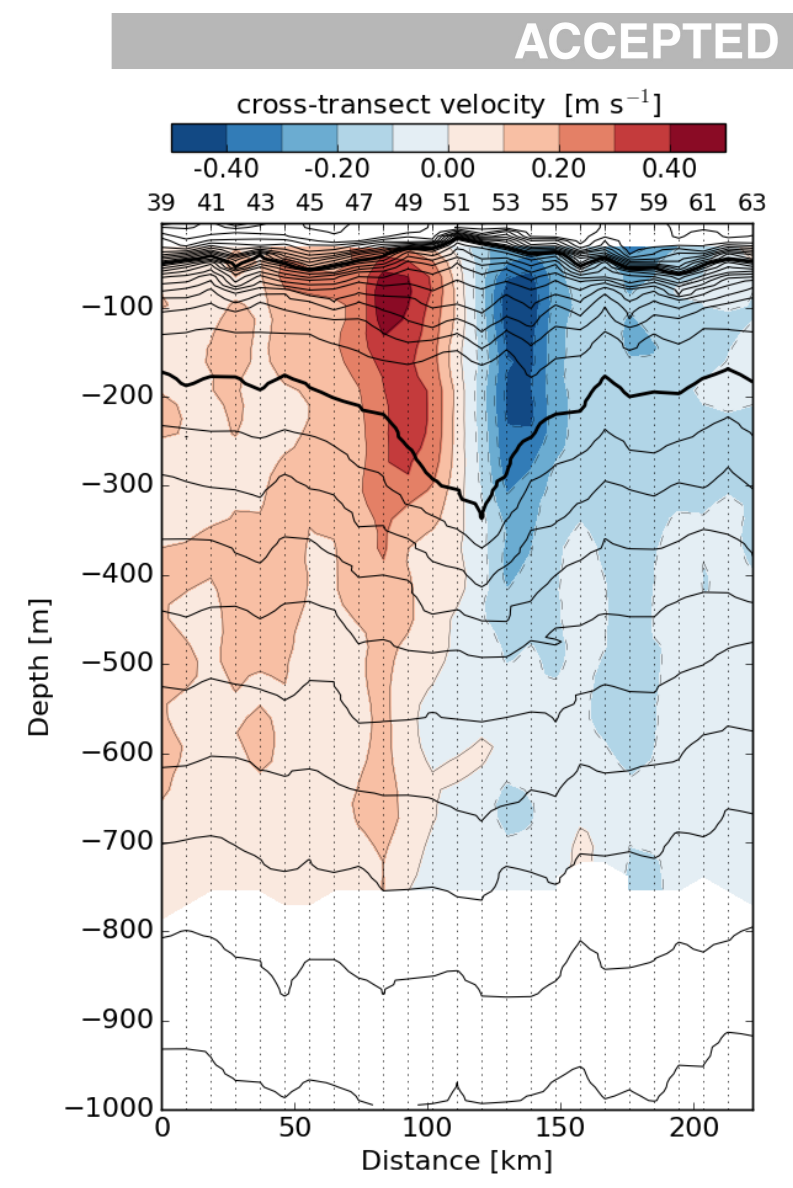

Figure 3: Vertical section of the cross-transect (zonal) ADCP velocity (positive values indicate eastward velocity and negative values indicate westward velocity) along the Le Tourmalet meridional transect (12-15 September 2014; Figure 1, white stars) with superimposed contours of potential density anomaly, $\sigma_{\Theta}$. Thick contours indicate $\sigma_{\Theta}=25.5$ $\mathrm{kg} \mathrm{m}^{-3}$ and $\sigma_{\Theta}=26.6 \mathrm{~kg} \mathrm{~m}^{-3}$ (contour interval is $0.1 \mathrm{~kg} \mathrm{~m}^{-3}$ ). Vertical dotted lines show the CTD station positions, only odd station numbers are included for clarity. 


\section{ACCEPTED MANUSCRIPT}

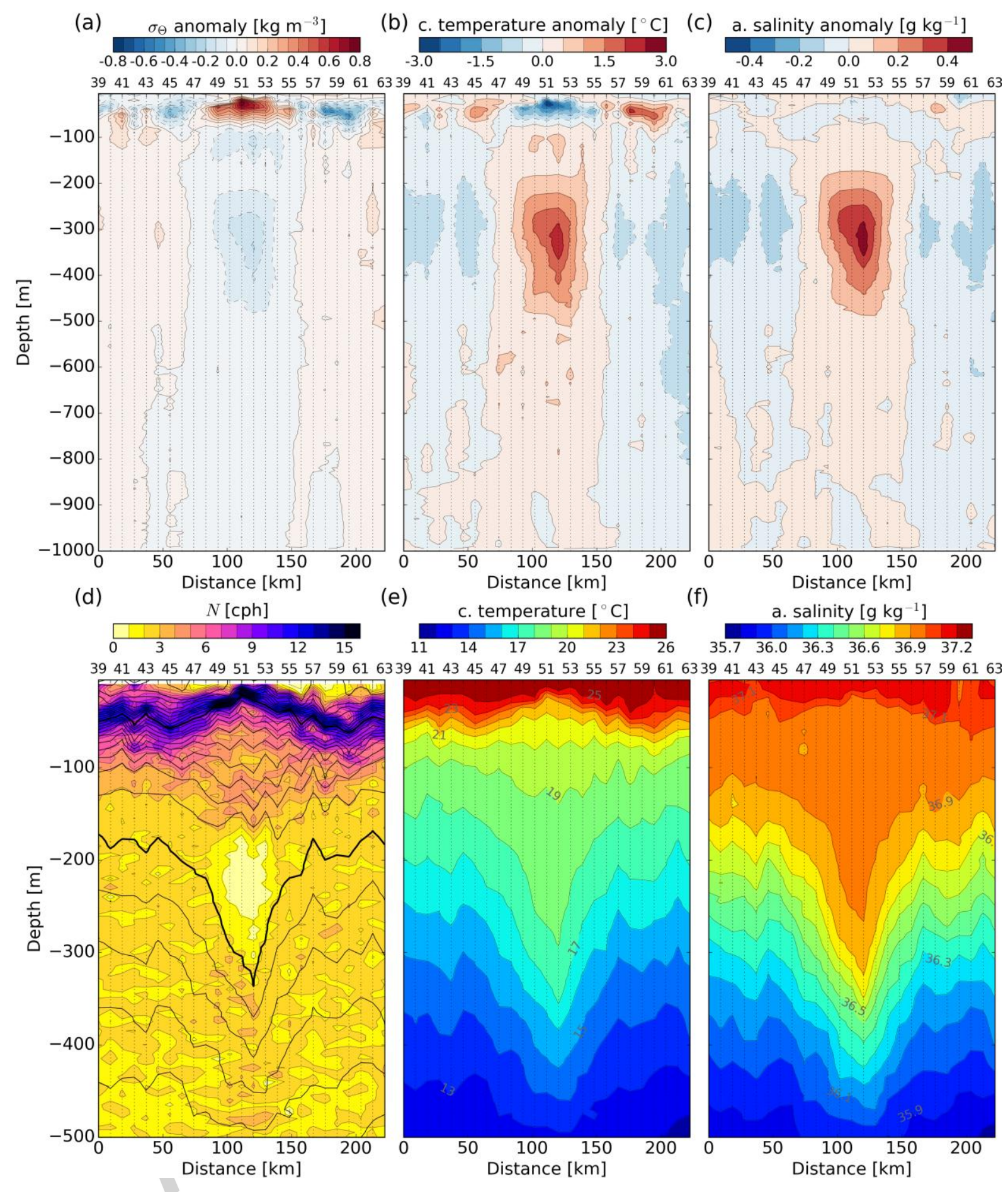

Figure 4: Vertical sections along the Le Tourmalet transect (Figure 1, white stars) of the anomalies of (a) potential density anomaly, $\sigma_{\Theta}$, (b) conservative temperature and (c) absolute salinity, computed with respect to the averaged value of the external casts $(39,40,62$ and 63$)$ at each depth. Vertical sections of the (d) Brunt-Väisälä frequency, $N$, (e) conservative temperature and (f) absolute salinity. Black contours in (d) represent $\sigma_{\Theta}$. Thick black contours indicate $\sigma_{\Theta}=25.5 \mathrm{~kg} \mathrm{~m}^{-3}$ and $\sigma_{\Theta}=26.6 \mathrm{~kg} \mathrm{~m}^{-3}$ (contour interval is $0.1 \mathrm{~kg} \mathrm{~m}^{-3}$ ). 


\section{ACCEPTED MANUSCRIPT}

Vertical dotted lines show the CTD station positions, only odd station numbers are included for clarity.

In order to detail the vertical structure of the PUMP eddy, in Figure 4d-f we zoom in on the upper $500 \mathrm{~m}$ of the water column. Vertical sections of conservative temperature and its anomaly (Figure 4e, b) show that the eddy is characterized by a narrow cold cap located at 30 $\mathrm{m}$ depth between stations 48 and 55 that is associated with seasonal thermocline shoaling, and by a deep warm core associated with deepening of the main thermocline which introduces a conservative temperature anomaly of ca. $+2.4{ }^{\circ} \mathrm{C}$. This warm core region is clearly recognizable in the conservative temperature anomaly section as the maximum anomaly located between stations 48 and 54; this region is $55 \mathrm{~km}$ wide and ranges from 200 to $500 \mathrm{~m}$ depth (Figure 4b). The signature of the deep eddy core is also evident in the vertical sections of $\sigma_{\Theta}$ and absolute salinity anomalies (Figures $4 \mathrm{a}, \mathrm{c}$ ) indicating that it is warmer, lighter and saltier than the surrounding waters. Therefore the vertical structure of the PUMP eddy shows a central deep core with sharp gradients of properties embraced by a peripheral region where the property gradients vary smoothly. We will refer to this deep region as the eddy hydrographic core.

A thermostad layer is also evident in the conservative temperature vertical section, trapped between the $18^{\circ} \mathrm{C}$ and $19^{\circ} \mathrm{C}$ isotherms (Figure 4e). This nearly homogeneous interior layer is also evident in the vertical distributions of $\sigma_{\Theta}$ and absolute salinity as the pycnostad and halostad, respectively (Figures 4d, f). In Figure 4d the Brunt-Väisälä frequency $N$ (defined as $N^{2}=-\left(g / \rho_{0}\right) \partial_{\mathrm{z}} \sigma_{\theta}$, where $\mathrm{g}$ is gravity and $\rho_{0}=1026 \mathrm{~kg} \mathrm{~m}^{-3}$ is the mean density) section shows the minimum in static stability introduced by this nearly homogeneous layer. The anomaly maxima introduced by the eddy reach the lower limit of the eddy hydrographic core region located at $500 \mathrm{~m}$, which may be considered as the eddy base or eddy depth (Figures 4a-c). Therefore, we may state that although the PUMP eddy has a vertical extension of $\sim 500 \mathrm{~m}$ depth, it perturbs the water column to at least the maximum sampled depth (1000 m).

The PUMP eddy also has a particular signature in the dissolved oxygen (DO) field. A vertical section of DO across the eddy center (Figure 5a) shows the eddy has maximum values at the seasonal pycnocline. In particular, at the eddy hydrographic core, where the 


\section{ACCEPTED MANUSCRIPT}

deeper part of the pycnostad is located, there is a well oxygenated column stretching from the seasonal pycnocline to the deeper layers accompanying the isopycnal deepening. We also derive the apparent oxygen utilization (AOU), which is the difference between saturated and observed DO concentrations (Figure 5b). Therefore, a negative AOU indicates a DO excess in the water column, while a positive AOU indicates deficiency. According with the DO maximum at the seasonal pycnocline, there is a band of negative AOU which may be explained by in situ phytoplankton production. At the pycnostad there is a column of low AOU with respect to the surrounding waters. These low local values are well below the euphotic layer, thus being suggestive of subduction of rich DO negative AOU waters from the upper layers at the eddy center.

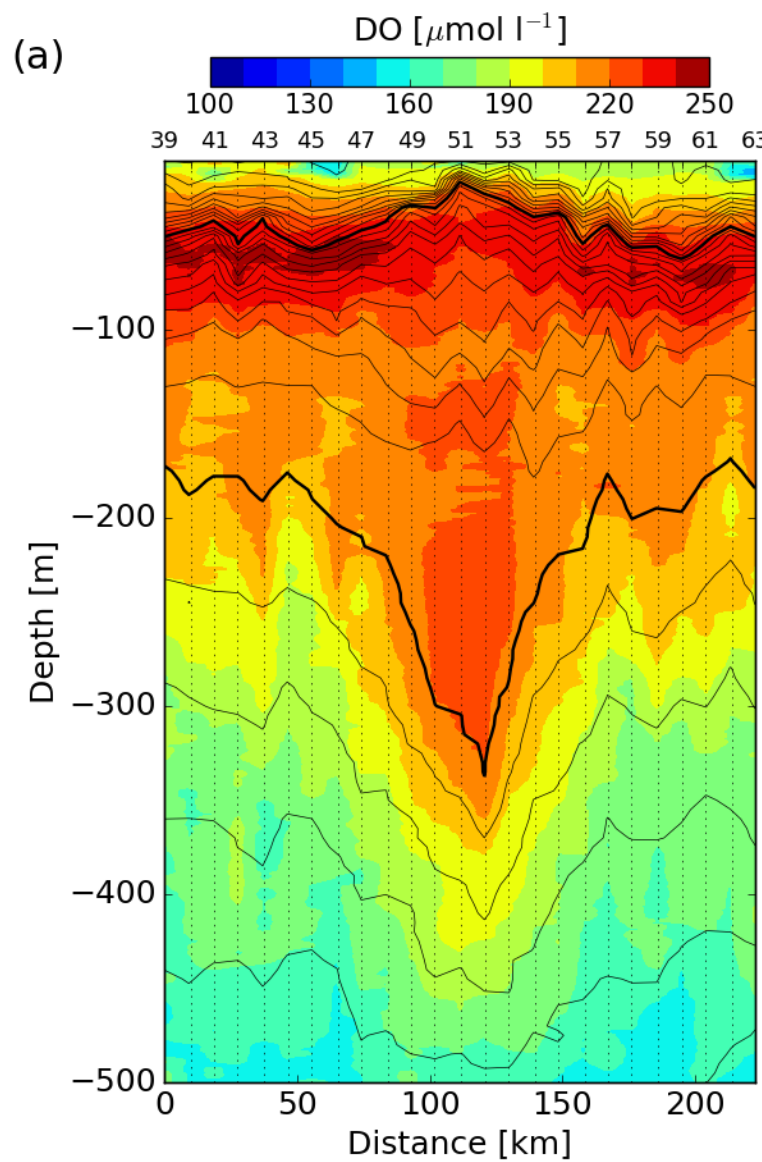

(b)
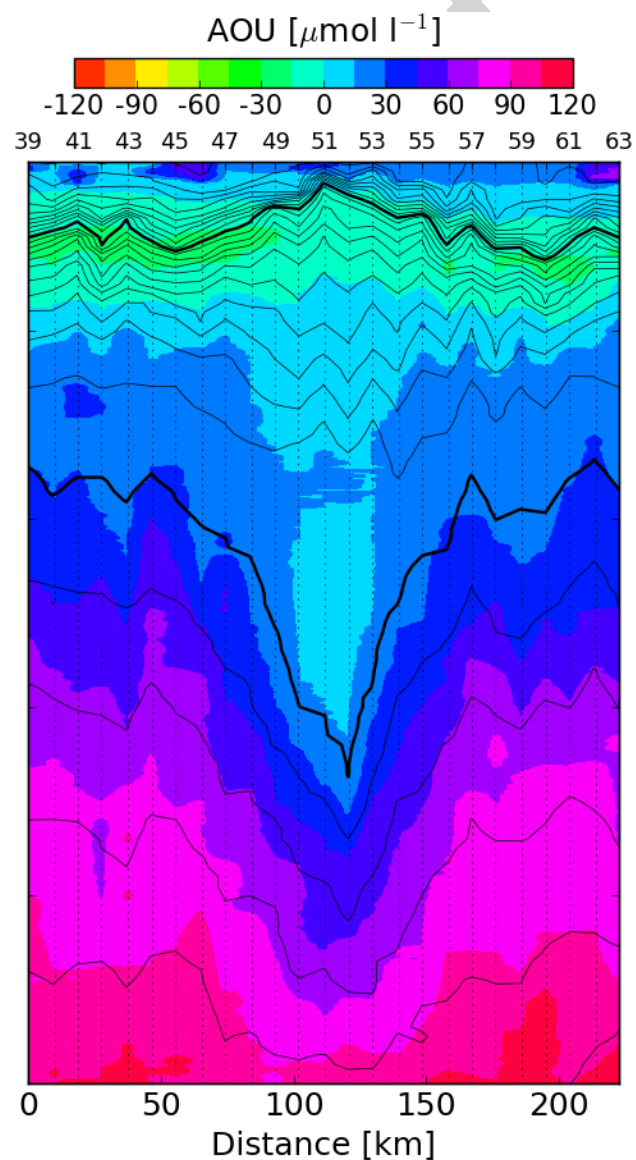

Figure 5: Vertical sections of (a) Dissolved oxygen (DO) and (b) apparent oxygen utilization (AOU) along the Le Tourmalet transect (Figure 1, white stars). Contours represent potential density anomaly, $\sigma_{\Theta}$. Thick contours are the $25.5 \mathrm{~kg} \mathrm{~m}^{-3}$ and $26.6 \mathrm{~kg} \mathrm{~m}^{-3}$ isopycnals (contour interval is $0.1 \mathrm{~kg} \mathrm{~m}^{-3}$ ). 


\section{ACCEPTED MANUSCRIPT}

\section{3D fields and dynamical variables}

As explained in Section 2, after sampling the eddy with two SeaSoar transects (Phase 1), from where the eddy center was located and the radius estimated, a $166.68 \times 166.68 \mathrm{~km}$ grid of $18.52 \times 18.52 \mathrm{~km}$ resolution was sampled combining rosette casts at discrete stations with SeaSoar tows (Phase 2). 3D fields were obtained by objectively interpolating the CTD and ADCP data onto a regular grid of $11 \times 11 \mathrm{~km}$ horizontal resolution and with a vertical resolution of $8 \mathrm{~m}$ (Bretherton et al., 1976; Le Traon, 1990). The data covariance was fitted with a 2D Gaussian function with semimajor and semiminor axes of $\mathrm{Lx}=\mathrm{Ly}=40 \mathrm{~km}$ ( eddy radius). The mean fields were assumed to be planar for density and constant for ADCP velocity (Rudnick, 1996). The uncorrelated noise applied for the computation is $3 \%$ of the signal energy. The resulting interpolated fields provide a smoothed picture of the eddy when compared to the Le Tourmalet near submesoscale resolution transect. Figure 6 shows horizontal maps of $\sigma_{\Theta}$ at selected depths with the ADCP velocity vectors superposed. A horizontal map at the depth of the cold cap (Figure 6a) shows the eddy signature at the center of the grid, with a density maximum at its center corresponding to the doming of the seasonal pycnocline. The eddy is delimited by the $25.5 \mathrm{~kg} \mathrm{~m}^{-3}$ isopycnal and has an elliptical shape with its major axis oriented NW-SE and an aspect ratio (ar) of ar $=155 \mathrm{~km} / 89 \mathrm{~km}=1.7$. This density distribution resembles Figure 6 of Viúdez and Dritschel (2003) that shows a filamented numerical eddy. In this regard, both vertices of the elliptic PUMP eddy show elongated structures which may be the roots of corresponding filaments. The corresponding velocity field for the cap section clearly shows asymmetry, with minimum speeds in the northern part of the eddy. 


\section{ACCEPTED MANUSCRIPT}

(a)

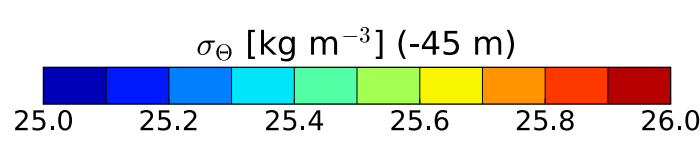

(b)

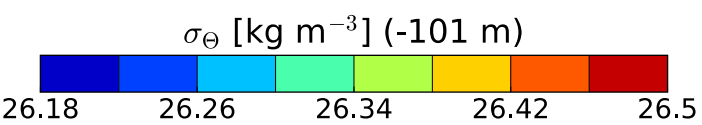

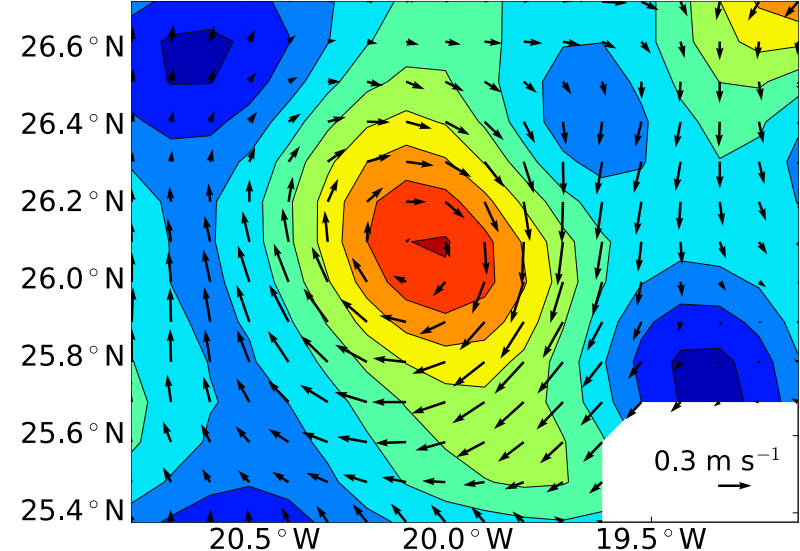

(c)

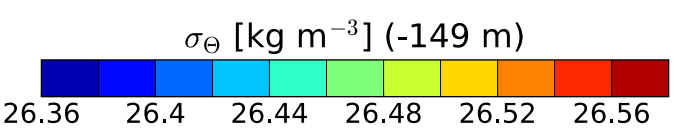

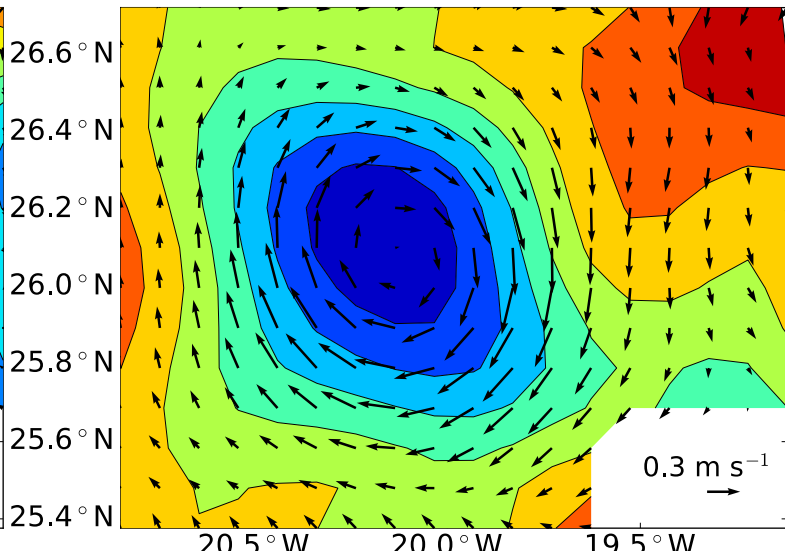

(d)

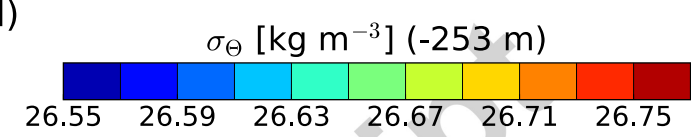

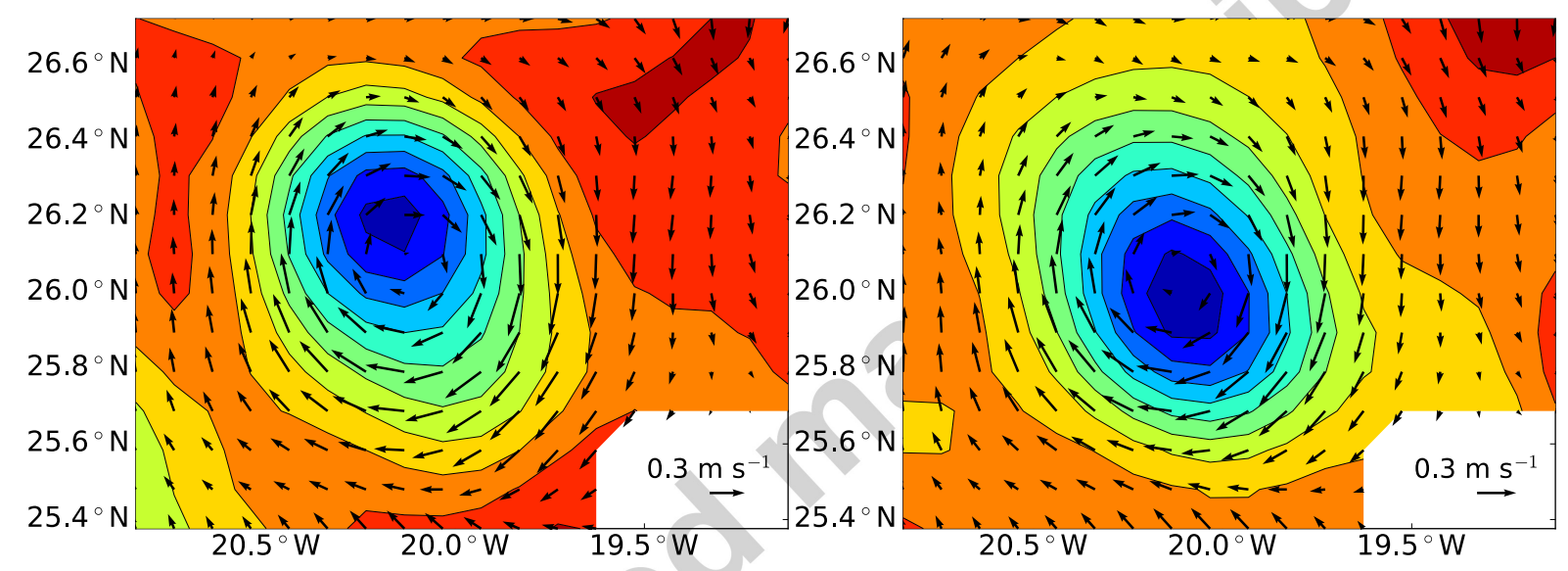

Figure 6: Objectively mapped ADCP velocity vectors with $\sigma_{\Theta}$ contours at different depths. Correlation scales used in the objectively interpolation are $L_{x}=L_{y}=40 \mathrm{~km}$ and the uncorrelated noise applied is $3 \%$.

As shown in Figure 6 the eccentricity of the eddy decreases with depth. Its center is displaced first westward (Figure 6c) and then southward (Figure 6d) with increasing depth, indicating that the eddy is vertically tilted. This tilting is clearly recognizable in the zonal section of $\sigma_{\Theta}$ (Figure 7a), where the main pycnocline is displaced westward from the surface cap. Figure $7 \mathrm{~b}$ shows the meridional component of the geostrophic flow computed through the thermal wind balance relations applying the ADCP data at the reference level $(325 \mathrm{~m}$ depth). This smoothed section with respect to the Le Tourmalet section allows us to clearly see that the geostrophic velocity subsurface maximum coincides with the limiting region between the seasonal pycnocline doming and the permanent pycnocline deepening. Figure $7 \mathrm{a}$ 


\section{ACCEPTED MANUSCRIPT}

also shows the meridional component of the ADCP velocity. The departure from geostrophy depicted in Figure 7c is greater in the upper $100 \mathrm{~m}$ depth where the eddy-wind interaction is intensified. The dominance of an overall anticyclonic circulation indicates that $|\boldsymbol{u}|>\left|\boldsymbol{u}^{g}\right|$.

(a)

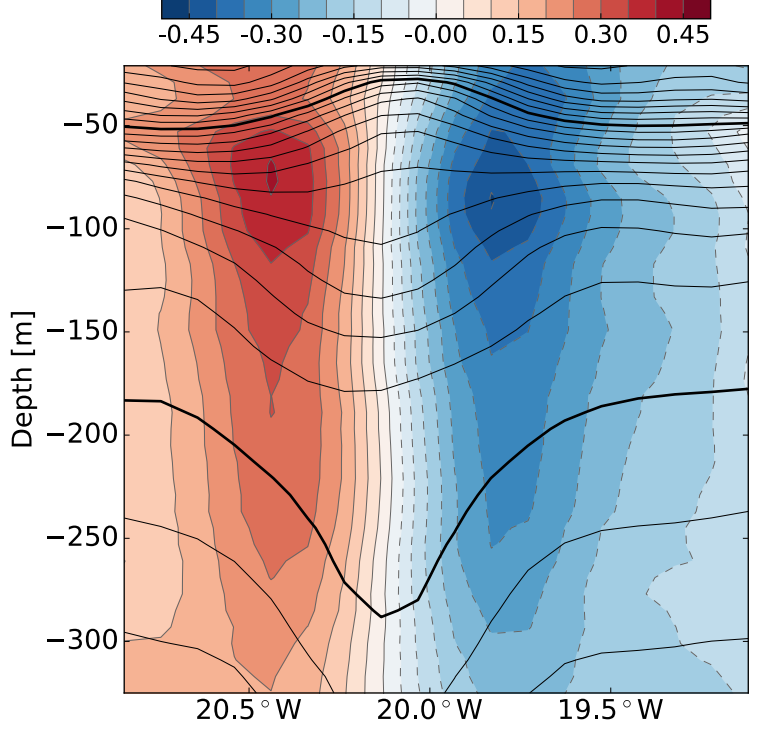

(b)
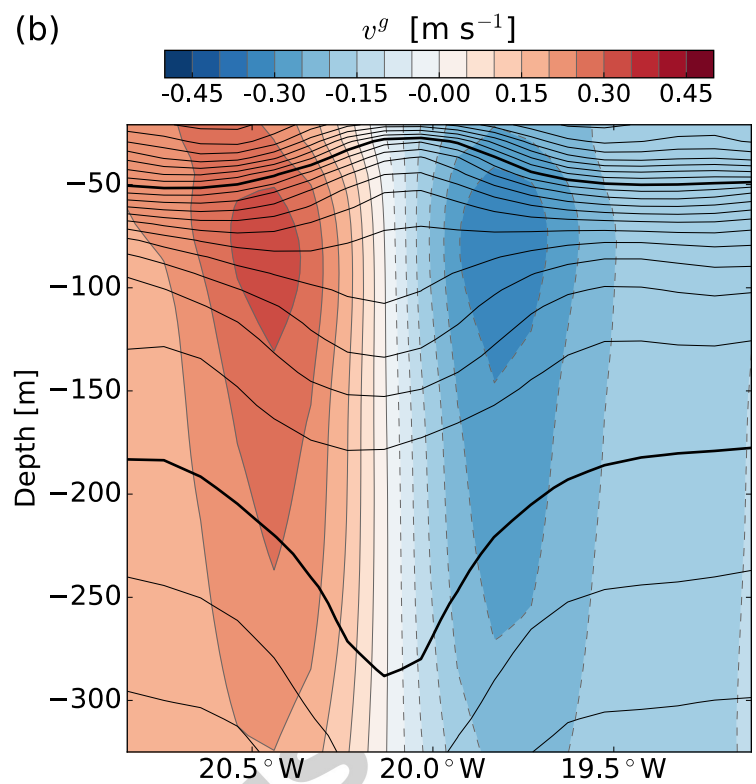

(c)
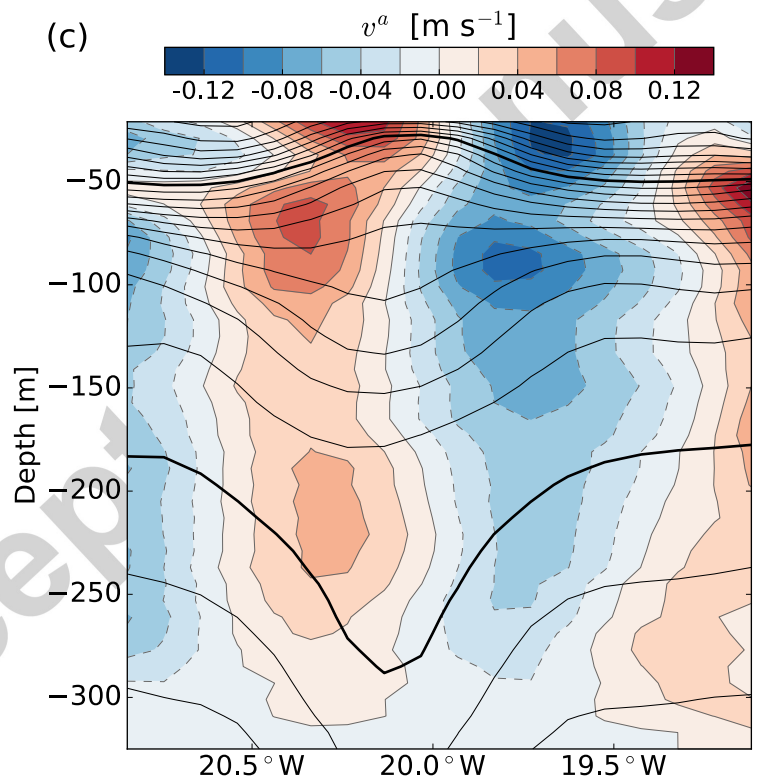

Figure 7: Vertical distributions of the meridional components of the (a) objectively mapped ADCP velocity, $v$, (b) geostrophic velocity, $v^{g}$, and (c) ageostrophic velocity, $v^{a}=v-v^{g}$, along $26.1^{\circ} \mathrm{N}$. Black contours correspond to the objectively mapped potential density anomaly $\left(\sigma_{\Theta}\right.$, with a contour interval of $\left.0.1 \mathrm{~kg} \mathrm{~m}^{-3}\right)$. Thick contours are the $25.5 \mathrm{~kg} \mathrm{~m}^{-3}$ and $26.6 \mathrm{~kg} \mathrm{~m}^{-3}$ isopycnals. Note different color scale in (c). 


\section{ACCEPTED MANUSCRIPT}

Figure 8a shows the horizontal distribution of the ADCP velocity magnitude at $85 \mathrm{~m}$ depth. Maximum values higher than $0.3 \mathrm{~m} \mathrm{~s}^{-1}$ are located around the eddy center except at the northern edge of the eddy where the ADCP velocity diminishes. As the ADCP velocity is anticyclonic in all the sampled domain we can refer the ADCP velocity magnitude as speed under the influence of the eddy, or eddy speed. A vertical profile of the horizontally averaged ADCP velocity magnitude is shown in Figure 8b. A subsurface maximum is located between 80 and $100 \mathrm{~m}$ depth, from this depth the speed decreases to the maximum available ADCP depth $(625 \mathrm{~m})$. This subsurface maximum region will be referred to as the eddy dynamical core. Recall that the eddy base depth as derived from the anomaly fields is $500 \mathrm{~m}$, below which the horizontally averaged eddy speed is still significant indicating that the eddy influences the water column well below its base. If the eddy swirl velocity is faster than the translation speed, the eddy is non-linear (Flierl, 1981; Chelton et al., 2007). This is an important property because, in this case, water parcels will remain trapped inside the eddy and the surrounding water will be prevented from entering the eddy. Therefore, in a nonlinear eddy the transported property anomalies will be maintained inside the eddy. In the case of the PUMP eddy the horizontally averaged eddy speed exceeds the translation speed over the full depth range, thus suggesting strong nonlinearity. The eddy translation speed of $4 \mathrm{~km}$ day $^{-1}$ westwards $\left(0.046 \mathrm{~m} \mathrm{~s}^{-1}\right.$, dashed line in Figure $8 \mathrm{~b}$ ) was derived from the eddy center displacement between the north-south SeaSoar transect in Phase 1 (Figure 1, cyan line) and the Le Tourmalet transect (Figure 1, white stars). 


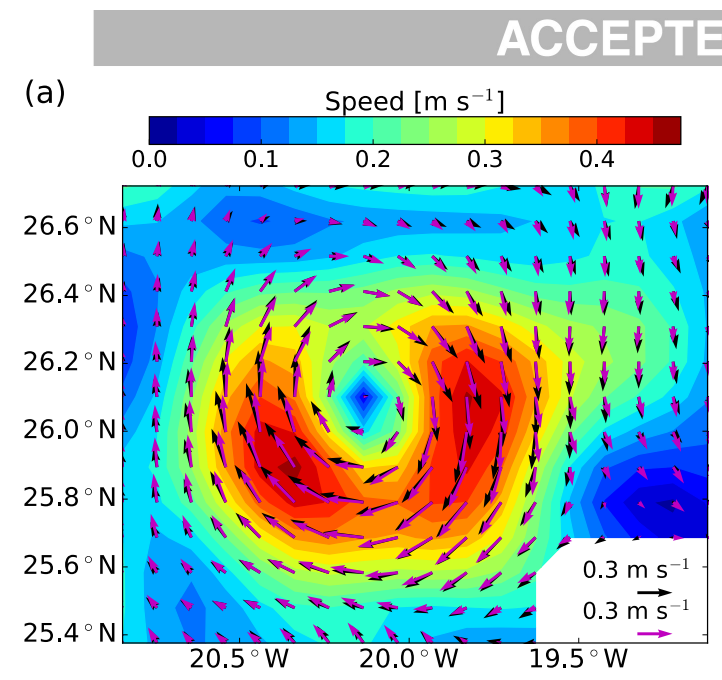

(b)

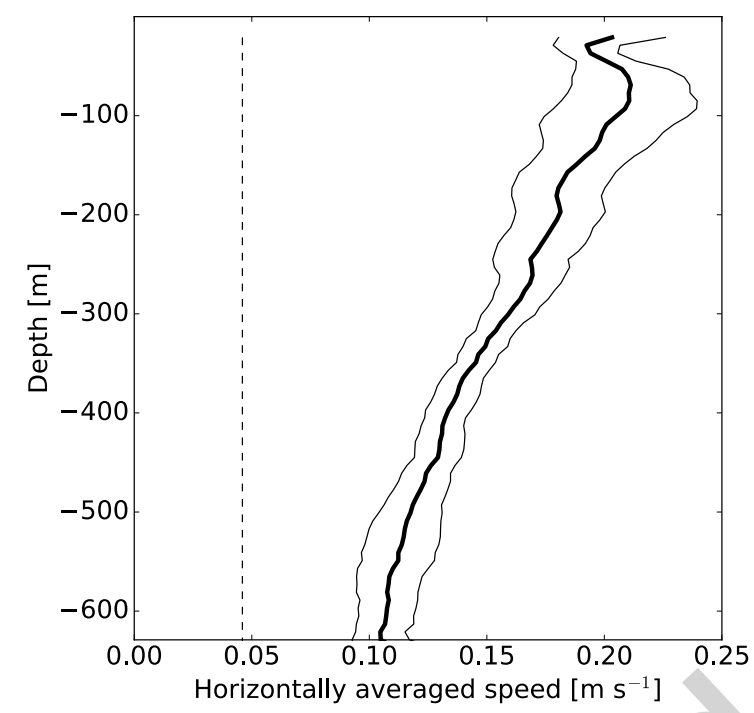

Figure 8: (a) ADCP velocity magnitude at $85 \mathrm{~m}$ depth. Black arrows represent ADCP velocity vectors whereas magenta arrows correspond to geostrophic velocity vectors. (b) Vertical profile of the horizontally averaged ADCP velocity magnitude (thick black line) with the standard deviation represented by thin black lines. Dashed line indicates the mean translation speed $\left(0.046 \mathrm{~m} \mathrm{~s}^{-1}\right)$.

The vertical component of the relative vorticity field, $\zeta$, scaled by the planetary vorticity, $f$, (or Rossby number, Ro $=\zeta / f$ ) is presented in Figure 9 and clearly shows the signature of the eddy as a well defined region of negative relative vorticity. A minimum relative vorticity value of $-0.6 f$ is attained at the eddy dynamical core, increasing rapidly towards its periphery. The zonal vertical section crossing the eddy center (Figure 9b) shows, as for the velocity field, that the relative vorticity minimum values are just below the eddy cap (at the eddy dynamical core) with increasing values both above and below. 


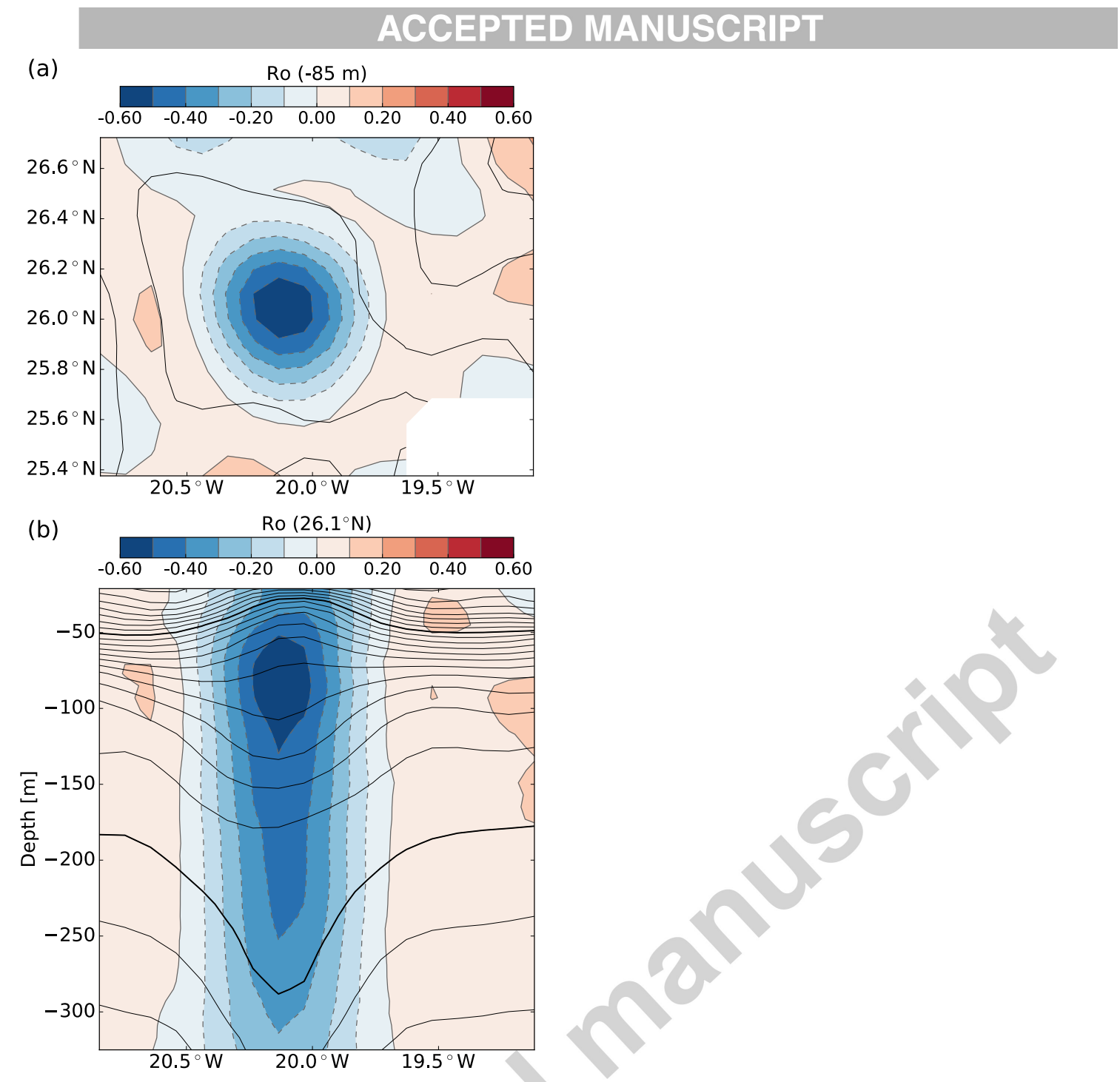

Figure 9: (a) Rossby number, Ro, horizontal distribution at $85 \mathrm{~m}$ depth. (b) Ro zonal section along $26.1^{\circ} \mathrm{N}$. Black contours indicate the objectively mapped $\sigma_{\Theta}$, with a contour interval of $0.1 \mathrm{~kg} \mathrm{~m}^{-3}$. Thick contours are the $25.5 \mathrm{~kg} \mathrm{~m}^{-3}$ and $26.6 \mathrm{~kg} \mathrm{~m}^{-3}$ isopycnals.

Details of the radial variability of the relative vorticity or related eddy rotation rate may be inferred from the high resolution Le Tourmalet transect. With this purpose we have plotted in Figure 10 the corresponding radial profiles of the absolute azimuthal velocity and the period at the depth of maximum horizontal velocity, which is attained at the eddy dynamical core. The period is derived from the angular velocity, which is approximated by the azimuthal velocity divided by the radial distance. Azimuthal velocity shows a rapid linear increase from minimum values at the eddy center to maximum value at $30 \mathrm{~km}$. From this radial limit, the velocity drops rapidly at first then more slowly. Our approximation of the radial period indicates that the inner region is in near solid body rotation, with an approximate rotation period of 4 days. We will refer to this inner region as the eddy core. 


\section{ACCEPTED MANUSCRIPT}

Beyond the eddy core edge (eddy core radius $R_{c}=30 \mathrm{~km}$ ) the rotation rate rapidly decreases. Therefore the PUMP eddy is composed of an inner core region in fast solid body rotation and a thin outer ring that rotates much more slowly. We may also derive the rotation rate and scaled relative vorticity (Rossby number) at the eddy center from the local slope of the azimuthal velocity profile at the origin, as done by Caldeira et al. (2014) (solid line Figure 10a). The rotation period at the eddy center is 3.7 days, and the absolute value of the scaled relative vorticity $|\mathrm{Ro}|=0.61$ which agrees with the value computed from the coarser resolution 3D data.

(a)

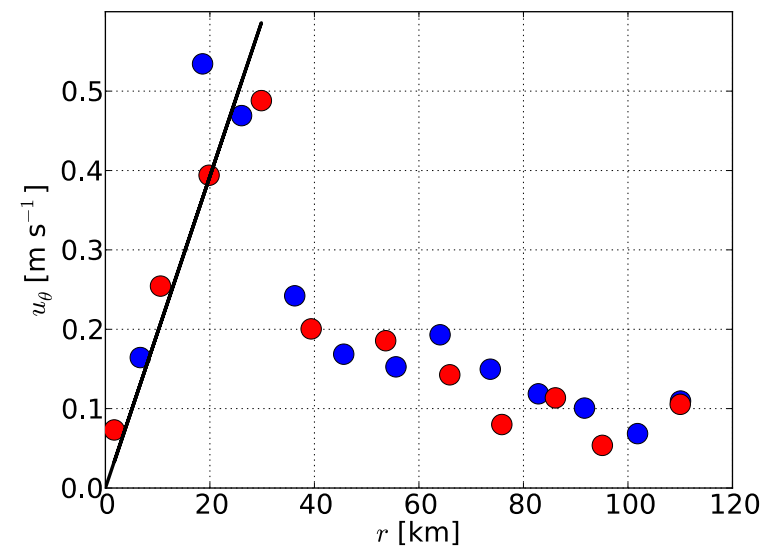

(b)

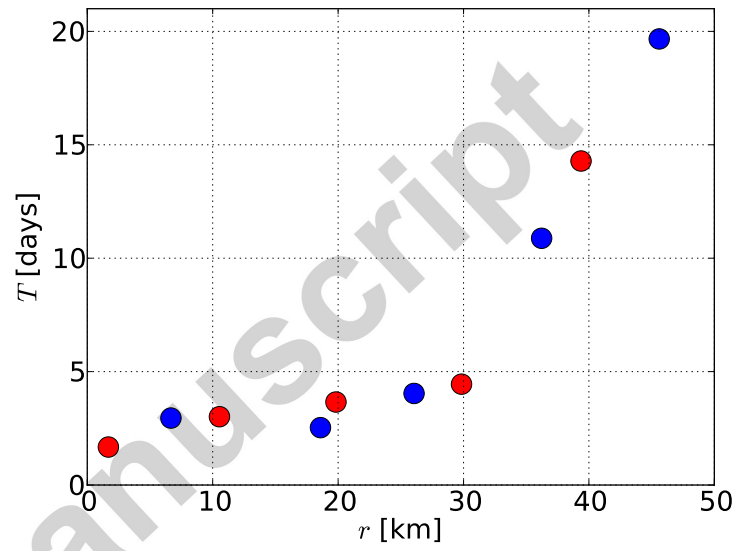

Figure 10: Radial sections of absolute azimuthal velocity, $u_{\theta}$, (a) and orbital period (b) for the Le Tourmalet transect (Figure 1, white stars). Sections are taken at the depth of maximum azimuthal velocity (97 $\mathrm{m}$ for the Le Tourmalet transect). Solid line in (a) shows the linear fit $u_{\theta}=\omega_{0} r$, with $\omega_{0}=1.96 \cdot 10^{-5} \mathrm{~s}^{-1}$ (angular velocity). (b) Represents the radial distribution of the orbital period computed as $2 \pi r / u_{\theta}$. Red and blue dots represent $u_{\theta}$ and T positions north and south of the eddy center, respectively.

A mesoscale eddy can be described as a potential vorticity anomaly relative to its surrounding waters (Allen et al., 2012). Ertel's potential vorticity (PV) can be expressed as:

$$
P V=-\frac{\left(-\partial_{z} v, \partial_{z} u\right) \cdot \nabla_{h} \sigma_{\theta}}{\rho_{0}}-\frac{(\zeta+f) \partial_{z} \sigma_{\theta}}{\rho_{0}}
$$

where $\rho_{0}=1026 \mathrm{~kg} \mathrm{~m}^{-3}$ is the mean density. The first term on the right hand side is named the tilting term while the second is the stretching term, which involves the vertical gradient of the potential density anomaly, $\sigma_{\Theta}$. For the PUMP eddy the tilting term is two orders of magnitude 


\section{ACCEPTED MANUSCRIPT}

smaller than the stretching term (not shown). Hence, the stretching term, and, in consequence, the vertical gradient of density (stratification or static stability), dominates the PV distribution. Therefore, it is expected that intrathermocline eddies will contain negative anomalies of PV as they lower the background static stability. A PV zonal section crossing the eddy center (Figure 11) indicates that, overall, the eddy signal lowers the PV, introducing a negative anomaly, and also there is some vertical variability that merits examination. In the near surface layer, between the surface and ca. $30 \mathrm{~m}$, the strong stratification introduced by the isopycnal doming increases PV, introducing a positive anomaly (Figure 11b). Then, the PV decreases reaching a first local minimum between 75 and $110 \mathrm{~m}$, where the bending of the isopycnals generates a local minimum of the static stability (Figure 11a). This minimum PV region coincides with the location of the eddy dynamical core and, in consequence, with the location of the maximum subsurface ADCP velocity and relative vorticity. This first layer of low PV is reflected in the vertical section of the PV anomaly as a region of strong negative PV anomaly and ranges from 30 to $110 \mathrm{~m}$ (Figure 11b). Below, in the pycnostad layer between 175 and $325 \mathrm{~m}$, we observe a second much broader region of minimum PV (Figure 11a) which introduces lower negative anomalies in comparison with the upper minimum (Figure 10b). Between both the dynamical and hydrographical core regions of minimum PV there is a relatively narrow layer of PV that is higher than the surrounding waters, ranging from 110 to $175 \mathrm{~m}$ (Figure 11a).
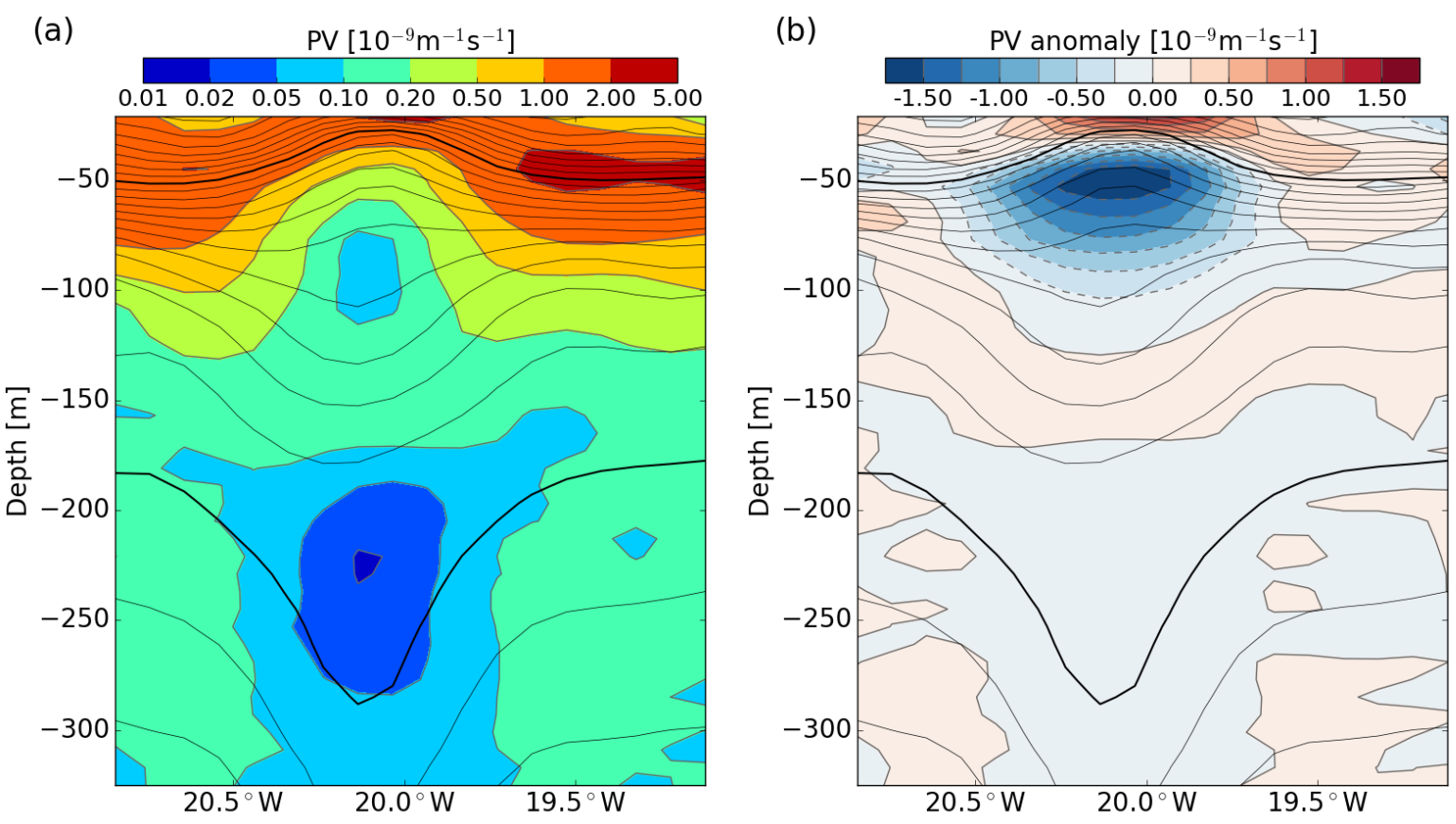


\section{ACCEPTED MANUSCRIPT}

Figure 11: (a) Potential vorticity and (b) potential vorticity anomaly zonal sections along $26.1^{\circ} \mathrm{N}$. The potential vorticity anomaly is computed with respect to the averaged external grid values for each depth layer. Black contours indicate the objectively mapped $\sigma_{\Theta}$, with a contour interval of $0.1 \mathrm{~kg} \mathrm{~m}^{-3}$. Thick contours are the $25.5 \mathrm{~kg} \mathrm{~m}^{-3}$ and $26.6 \mathrm{~kg} \mathrm{~m}^{-3}$ isopycnals.

\section{Energetics}

To infer the eddy content of available potential energy (APE) and kinetic energy (KE), we selected CTD and ADCP data from the Le Tourmalet meridional transect and followed the methodology proposed by Schultz et al. (1991). From Hebert (1988) and assuming that the eddy has a circular shape, APE is estimated using the integral:

$$
\mathrm{APE}=0.5 \rho_{r} \int_{-500}^{0} \int_{0}^{R} N_{r}^{2} \delta^{2}(2 \pi r) d r d z
$$

where $\rho_{r}$ and $N_{r}$ are the density and the Brunt-Väisälä frequency of the reference state, and $\delta$ is the vertical displacement of the isopycnals within the eddy from the reference state. The reference state is the mean field as estimated from all CTD stations located at least $70 \mathrm{~km}$ from the eddy center. The integration is performed from the surface to the base of the eddy, located at $500 \mathrm{~m}$, and from the eddy center to its radius, $R=46 \mathrm{~km}$.

The total KE contained by the eddy is estimated using the integral:

$$
\mathrm{KE}=0.5 \rho_{r} \int_{-500}^{0} \int_{0}^{R} \boldsymbol{u}^{2}(2 \pi r) d r d z
$$

where $\boldsymbol{u}$ is the horizontal velocity as obtained from the ADCP. The resulting APE and KE for the PUMP eddy are APE $=5.64 \times 10^{13} \mathrm{~J}$ and $\mathrm{KE}=8.88 \times 10^{13} \mathrm{~J}$. These quantities are two orders of magnitude smaller than those corresponding to large eddies such as Gulf Stream or Aghulas rings (Olson et al., 1985; Clement and Gordon, 1995). However, if they are compared with corresponding eddies of similar size they are of the same order of magnitude (Table 1).

The PUMP eddy contains more KE than APE, with the energy Burger number (D'Asaro, 1988) greater than unity, $B_{E}=\mathrm{KE} / \mathrm{APE}=1.58$. As shown in Table 1 this higher 


\section{ACCEPTED MANUSCRIPT}

content of KE than APE is a particularity of the PUMP eddy when compared with other eddies of similar size. The obtained $B_{E}$ value is intermediate between those reported for large eddies, where the APE content exceeds the KE content leading to values of $B_{E}<1$ (Schmid et al., 1995; Clement and Gordon, 1995), and those reported for small submesoscale vortices where $B_{E}>1$ (D'Asaro, 1988). Prater and Sanford (1994) derived a relationship between $B_{E}$ and the length-scale Burger number $\left(B_{L}=N^{2} H^{2} / f^{2} L^{2}\right)$ and Rossby number, Ro:

$$
B_{E}=\frac{\mathrm{KE}}{\mathrm{APE}} \approx \frac{B_{L}}{(1+\mathrm{Ro})^{2}}
$$

Using the background $N^{2}$, the eddy diameter $L=92 \times 10^{3} \mathrm{~m}$ and the eddy depth $H=500 \mathrm{~m}$, the eddy length-scale Burger number is $B_{L}=0.20$. With the eddy Rossby number based on the 3D data (Figure 9) as Ro $=-0.6, B_{E}$ is 1.25 , which is very close to the value calculated above from the ratio $\mathrm{KE} / \mathrm{APE}=1.58$. This scaling analysis of $B_{E}$ suggests that $B_{E}>1$ is due both to a small aspect ratio, indicated by small $B_{L}$, and a relatively intense spin rate as indicated by a relatively large Ro. In this regard, notice that the eddies compared in Table 1 have similar aspect ratios but smaller Ro than the PUMP eddy, which has a consistently smaller $B_{E}$.

Table 1: Energetics. Kinetic energy (KE) and available potential energy (APE) contents. R is the eddy radius, $H$ is the eddy thickness and $L$ is the eddy diameter.

\begin{tabular}{llll}
\hline $\begin{array}{l}\text { Author, description, } \\
\text { location }\end{array}$ & PUMP & $\begin{array}{l}\text { Schmid et al. (1995), } \\
\text { Anticyclone Vitória eddy, } \\
\text { Brazil Current }\end{array}$ & $\begin{array}{l}\text { Hebert et al. (1990) and Schultz } \\
\text { Tokos and Rossby (1991), } \\
\text { Meddy, NE Atlantic }\end{array}$ \\
\hline KE $\left(\times 10^{13} \mathrm{~J}\right)$ & 8.88 & 9.6 & 7.9 \\
$\mathrm{APE}\left(\times 10^{13} \mathrm{~J}\right)$ & 5.64 & 19 & 7.5 \\
$\mathrm{KE} / \mathrm{APE}$ & 1.58 & 0.51 & 1.1 \\
Eddy radius, $\mathrm{R}(\mathrm{km})$ & 46 & 50 & 65 \\
Eddy thickness, $H(\mathrm{~m})$ & 500 & 400 & 900 \\
H/L $\left(\times 10^{-2}\right)$ & 0.5 & 0.4 & 0.7 \\
Ro & 0.6 & $0.20-0.28$ & 0.3 \\
\hline
\end{tabular}

\section{Available heat and salt content anomalies}




\section{ACCEPTED MANUSCRIPT}

Available heat and salt content anomalies, AHA and ASA respectively, for the PUMP eddy were derived following the methodology of Chaigneau et al. (2011),

$$
\begin{gathered}
\mathrm{AHA}=\int_{-500}^{0} \int_{0}^{R_{c}} \rho C_{p} \Theta^{\prime}(2 \pi r) d r d z \\
A S A=0.001 \int_{-500}^{0} \int_{0}^{R_{c}} \rho S^{\prime}(2 \pi r) d r d z
\end{gathered}
$$

where $C_{p}$ is the specific heat capacity (4000 $\mathrm{J} \mathrm{kg}^{-1} \mathrm{~K}^{-1}$ ), $\rho$ the density, and the conservative temperature and absolute salinity anomalies $\left(\Theta^{\prime}\right.$ and $\left.S^{\prime}\right)$ are integrated over the area of the eddy core (assuming a circular shape) and then vertically integrated over the vertical extension of the eddy. To estimate these quantities we use the Le Tourmalet transect data as they reach the eddy base at $500 \mathrm{~m}$ depth. Temperature and salinity anomalies are computed with respect to the averaged value of the external casts $(39,40,62$ and 63) at each depth. We integrate radially from the eddy center to the eddy core radius $\left(R_{c}=30 \mathrm{~km}\right.$, Section 3$)$. Vertical profiles of available heat and salt anomalies integrated only over the eddy core area (Figure 12) show maximum (minimum) available contents of $0.014 \times 10^{18} \mathrm{~J} \mathrm{~m}^{-1}(-0.018 \times$ $\left.10^{18} \mathrm{~J} \mathrm{~m}^{-1}\right)$ and $0.065 \times 10^{10} \mathrm{~kg} \mathrm{~m}^{-1}\left(-0.020 \times 10^{10} \mathrm{~kg} \mathrm{~m}^{-1}\right)$ at $300 \mathrm{~m} \mathrm{(35} \mathrm{m)} \mathrm{depth,}$ respectively. Although these available anomalies have opposite signs in the vertical, positive anomalies are broader and the vertically integrated AHA and ASA contents of the PUMP eddy are $2.9 \times 10^{18} \mathrm{~J}$ and $14.3 \times 10^{10} \mathrm{~kg}$, respectively. The AHA and ASA contents are characteristics of the changing background along the eddy path, as well as of variation of eddy core properties with time due to exchange through eddy boundaries (e.g. Hebert et al., 1990).

Comparing the above values with those corresponding to intrathermocline eddies in other EBUS (Table 2), we notice that AHA and ASA contents are closely associated with the sizes of the eddies. The volume of trapped water transported by the PUMP eddy is $1.4 \times 10^{12}$ $\mathrm{m}^{3}$, while intrathermocline eddies generated in the Peru-Chile Current System (PCCS) have a mean volume of $5.5 \times 10^{12} \mathrm{~m}^{3}$ (Chaigneau et al., 2011). Hence, these eddies contain higher available heat and salt anomalies than the PUMP eddy. On the other hand, intrathermocline eddies generated by the California Undercurrent (Cuddies, Pelland et al., 2013) are smaller with an estimated volume of $0.56 \times 10^{12} \mathrm{~m}^{3}$. Furthermore, if we compare the relative contents of available heat and salt anomalies per unit volume it turns out that the PUMP eddy 


\section{ACCEPTED MANUSCRIPT}

transports warmer and saltier water than intrathermocline eddies of the PCCS and California EBUS. The PUMP eddy has an AHA per unit of volume almost double that of PCCS intrathermocline eddies, and more than three times that of Cuddies. On the other hand, ASA per unit volume in the PUMP eddy is more than two times higher than in PCCS eddies, and more than four times that of Cuddies. Therefore, in terms of units per volume the PUMP eddy ASA and AHA contents exceed those corresponding to the eddies analyzed here.

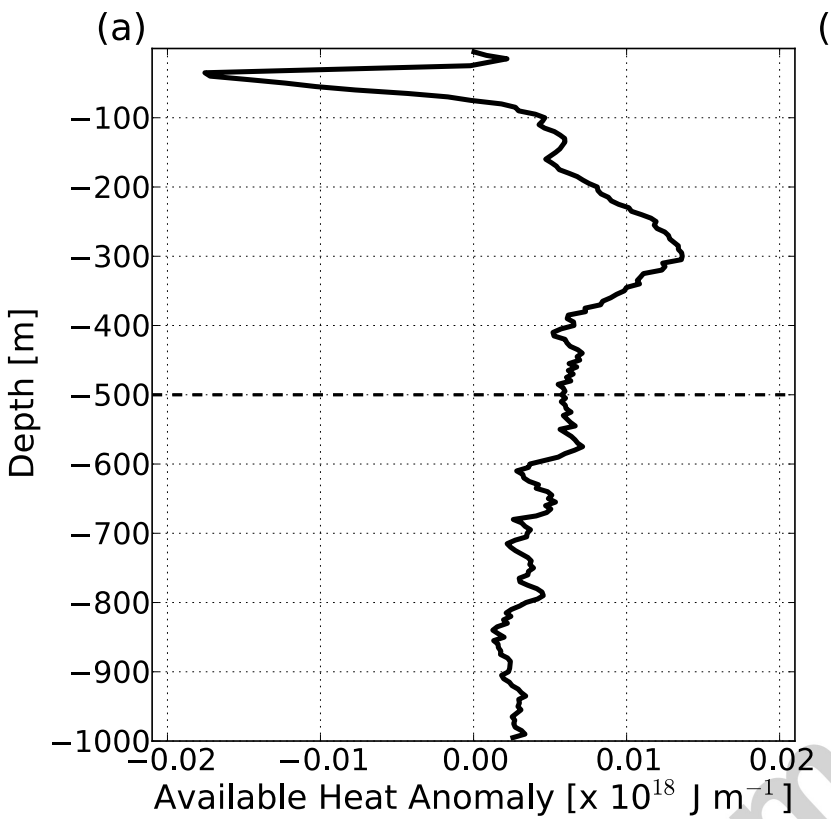

(b)

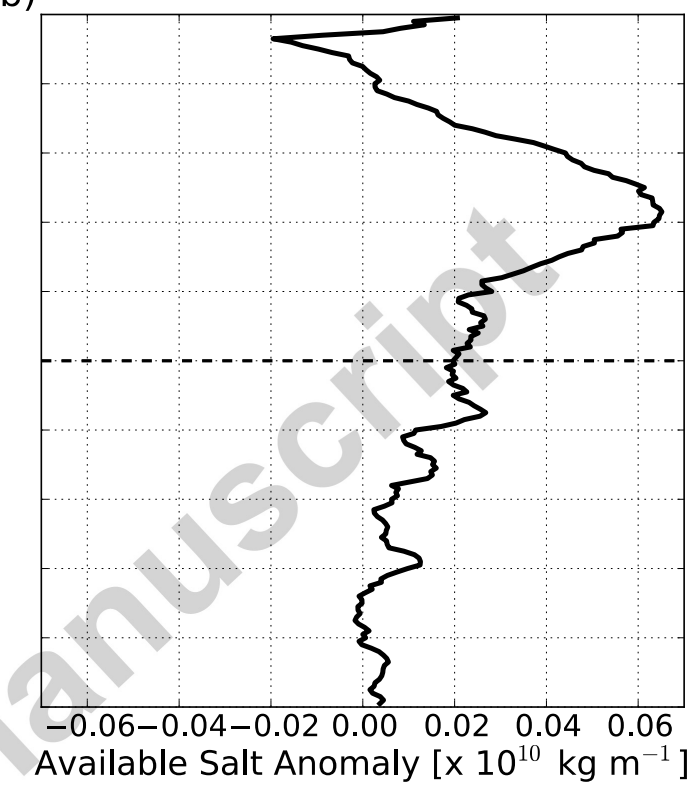

Figure 12: Vertical profiles of the available heat (a) and salt (b) content anomalies transported by the eddy core. Horizontal dashed lines represent the eddy base.

Table 2: Radius and vertical extent of the eddy core defined as the inner eddy region that is in solid body rotation. Volume, available heat anomaly (AHA), and available salt anomaly (ASA) trapped and transported by the eddy core. PCCS refers to Peru-Chile Current System while Cuddies are generated in the California EBUS. AHA* and ASA* are available heat and salt anomalies per unit volume, respectively.

\begin{tabular}{llll}
\hline & PUMP & $\begin{array}{l}\text { PCCS } \\
\text { Chaigneau et al. } \\
(2011)\end{array}$ & $\begin{array}{l}\text { Cuddies } \\
\text { Pelland et al. } \\
(2013)\end{array}$ \\
\hline Radius $(\mathrm{km})$ & 30 & 57.6 & 20.4 \\
Vertical extent $(\mathrm{m})$ & 500 & 540 & 429 \\
Volume $\left(\times 10^{12} \mathrm{~m}^{3}\right)$ & 1.4 & 5.5 & 0.56 \\
$\mathrm{AHA}\left(\times 10^{18} \mathrm{~J}\right) / \mathrm{AHA}^{*}\left(\times 10^{6} \mathrm{~J} \mathrm{~m}^{-3}\right)$ & $2.9 / 2.1$ & $8.7 / 1.6$ & $0.36 / 0.6$
\end{tabular}




\section{Discussion}

7.1 Negative potential vorticity anomaly and eddy structure

The PUMP eddy is characterized by a biconvex isopycnal shape with an embedded pycnostad layer. The biconvex shape, which occurs in the near surface layers, is associated with the vertical shear induced by the subsurface maximum of ADCP velocity in accordance with thermal wind balance. This vertical structure of the density field introduces a decrease of the static stability which induces a subsurface PV minimum and, hence, a negative PV anomaly (Figure 11). This subsurface region of negative PV anomaly, maximum absolute relative vorticity, and maximum ADCP velocity may be thought of as the eddy dynamical core. It is limited radially by the maximum azimuthal velocity and is in solid body rotation (Figure 10). Negative PV anomaly within the eddy and a central core rotating in solid body rotation surrounded by a more slowly rotating outer ring are defining properties of intrathermocline eddies (Schultz Tokos and Rossby, 1991; Gordon et al., 2002; Hansen et al., 2010).

Another common feature of intrathermocline eddies is the occurrence of a pycnostad, which is a homogenous density layer embedded within the eddy. In the case of the PUMP eddy the pycnostad is trapped between the $26.5 \mathrm{~kg} \mathrm{~m}^{-3}$ and $26.6 \mathrm{~kg} \mathrm{~m}^{-3}$ isopycnals and the corresponding thermostad between the $18^{\circ} \mathrm{C}$ and $19^{\circ} \mathrm{C}$ isotherms (Figure 4). As shown in Figure 6 of Arístegui et al. (1994) in May, the month of the PUMP eddy generation, the upper part of the water column in the eddy generation area (Canary Islands) shows a nearly vertically homogeneous subsurface water layer trapped between the $18{ }^{\circ} \mathrm{C}$ and $19{ }^{\circ} \mathrm{C}$ isotherms and capped by the seasonal thermocline. This layer has characteristics of subtropical mode water and is formed by winter convection that sets up a deep mixed layer which is subsequently capped by the seasonal thermocline (Arístegui et al., 1994; Hanawa and Talley, 2001). Therefore, the pycnostad embedded within the PUMP eddy contains mode water that may have been trapped inside the eddy during the eddy generation process. As already mentioned, Caldeira et al. (2014) describe an intrathermocline eddy generated by Madeira, which is located north of the Canaries. They also observed, at its early stage of formation, a pycnostad within the eddy core composed of Madeira Mode Water trapped within the $17^{\circ} \mathrm{C}-18{ }^{\circ} \mathrm{C}$ isotherms, thus being slightly cooler than the mode water trapped by 


\section{ACCEPTED MANUSCRIPT}

the PUMP eddy at the Canaries, 200 nautical miles to the south. This adds evidence to the hypothesis that the pycnostad embedded within the PUMP eddy is generated early in the eddy birth process as a consequence of trapping of subtropical mode water. Indeed, the trapping of well-mixed water during the eddy generation process is already observed in swoddies, generated in the northwestern coast of the Iberian Peninsula. Swoddies, although generated 1000 nautical miles to the north of the Canaries, usually have similar sizes as the PUMP eddy (see Introduction section). Moreover, they usually have a similar $|\mathrm{Ro}|$ of $0.4-0.5$, a rotation rate of the eddy center of 3-3.5 days and a saltier, warmer and lighter core than the surrounding waters (Pingree and Le Cann, 1992a, b; Sánchez and Gil, 2004).

Mode waters have clear signatures in PV fields as negative anomalies due to the local decrease of static stability which is conserved, and thus constitute reservoirs of low PV (Hanawa and Talley, 2001; Sato and Polito, 2014). This is reflected in our vertical section of PV where low static stability values at the pycnostad, the eddy hydrographic core, are associated with a second region of minimum PV (centered between 175 and $325 \mathrm{~m}$ depth). This deeper PV minimum is much broader than the upper PV minimum located at the dynamical core (Figure 11a). The negative PV anomaly that is introduced is, however, smaller than the upper layer PV anomaly (Figure 11b).

\subsection{Intrathermocline eddies in the Canary Eddy Corridor}

Pingree (1996) gave the first description of an intrathermocline eddy inside the Canary Eddy Corridor. The eddy was first detected by the trajectory of a drogued Argos buoy near $23^{\circ} \mathrm{W}$ and $26^{\circ} \mathrm{N}$ in February 1993 close to the location of the PUMP eddy $\left(20^{\circ} \mathrm{W}, 26^{\circ} \mathrm{N}\right)$. The similar location of both eddies in the Canary Eddy Corridor suggests that Pingree's (1996) eddy was also generated by the Canary Islands. The drogued buoy tracked the westward movement of the eddy for at least 20 months and the eddy was sampled in December 1993 at $33^{\circ} \mathrm{W}, 1000 \mathrm{~km}$ west of the location of the first observation. In the intervening period the seasonal thermocline had been replaced by a deep, $100 \mathrm{~m}$, mixed layer due to winter convection. The eddy was formed by a subsurface warm water lens located just below the mixed layer. Pingree (1996) named this structure the "shallow subtropical subducting westward propagating eddy" or Swesty.

In Table 3 we compare the characteristics of PUMP and Swesty eddies. At the time of the survey the ca. 18 months old Swesty was located ca. $1800 \mathrm{~km}$ from the Canary Islands 


\section{ACCEPTED MANUSCRIPT}

and migrating westward displacement at ca. $100 \mathrm{~km} \mathrm{month}^{-1}$. The PUMP eddy was younger, 4 months old, which may explain its shorter rotation period, greater central vorticity and stronger azimuthal current maximum when compared with Swesty values (Table 3). The PUMP eddy dynamical core was at $85 \mathrm{~m}$ depth whereas the Swesty dynamical core was at $190 \mathrm{~m}$. As they have probably the same origin, the deeper Swesty core may support Pingree's (1996) suggestion on core subduction as Swesties self-propagate westward along inclined isopycnals. Pingree estimated a subduction velocity of ca. $40 \mathrm{~m} \mathrm{y}^{-1}$, while the difference in the eddy core depths and their age provides an estimate of twice that figure. Like the PUMP eddy, the Swesty showed biconvex shape of the isopycnals associated with an anomaly of potential vorticity $91 \%$ below ambient potential vorticity (Table 3 ). It is expected that due to winter convection, subduction and lateral mixing the PUMP eddy may evolve towards Swesty characteristics as it propagates westwards.

Table 3: Swesty (Pingree, 1996) and PUMP eddy characteristics.

\begin{tabular}{lll}
\hline Property (units) & PUMP & Swesty \\
\hline Distance from the Canaries $(\mathrm{km})$ & 550 & 1887 \\
Age $($ month) & 4 & 18 \\
Radius $(\mathrm{km})$ & 46 & 60 \\
Vertical extent $(\mathrm{m})$ & 500 & 600 \\
Mixed layer above the core $(\mathrm{m})$ & 10 & 100 \\
Westward self propagation $\left(\mathrm{km} \mathrm{d}^{-1}\right)$ & 4 & 3.3 \\
Dynamical core depth $(\mathrm{m})$ & 85 & 190 \\
Temperature anomaly $\left({ }^{\circ} \mathrm{C}\right)$ & +3 & +1.5 \\
Core rotation period $(\mathrm{d})$ & 4 & 8 \\
Central vorticity, $\zeta / \mathrm{f}$ & -0.6 & -0.3 \\
Anomaly of potential vorticity below ambient $(\%)$ & 95 & 92 \\
Maximum azimuthal current velocity $\left(\mathrm{m} \mathrm{s}^{-1}\right)$ & 0.5 & 0.16 \\
Radius of maximum azimuthal current velocity $(\mathrm{km})$ & 30 & 30 \\
\hline
\end{tabular}

Pegliasco et al. (2015) recently investigated and compared the vertical structure of the eddy field in the four eastern boundary upwelling system (EBUS) from altimetry and Argo buoy data. They observed that $40 \%$ of anticyclonic eddies in the Canary EBUS are intrathermocline eddies. Most of those eddies are generated inside the Canary Eddy Corridor south of the Canary Islands, as was the PUMP eddy. The composite vertical structure of those eddies shows subsurface intensified temperature and salinity anomalies similar to the PUMP 


\section{ACCEPTED MANUSCRIPT}

and Swesty eddies. When comparing the composite vertical structures of subsurface eddies in other EBUS systems, one striking feature is that the Canary Eddy Corridor subsurface eddies have weaker anomalies and are shallower. This may be a response to their different origins. Cuddies of the California EBUS and subsurface eddies of the Peru-Chile EBUS have their origins in the poleward undercurrents of their respective upwelling systems (e.g., Pelland et al., 2013; Hormazabal et al., 2013). These are deeper structures than the PUMP eddy with maximum current velocity at depths of several hundred meters and minimum oxygen anomalies instead of maximum oxygen anomalies. Shallower anomalies in the Canary EBUS and the observations of the PUMP and the Swesty eddies are consistent with the Canary Islands being the main source of intrathermocline eddies for the Canary Eddy Corridor, and with the domination of this shallower eddy type over deeper, low oxygen intrathermocline type eddies originating in the poleward undercurrent at the African coastal margin. South of the Canary Eddy Corridor the percentage of subsurface eddies decreases dramatically to $9 \%$ and are deeper subsurface intensified type (Schütte et al., 2015).

\section{Summary and conclusions}

The Canary Eddy Corridor is the main pathway of long-lived eddies for the northeastern subtropical Atlantic (Sangrà et al., 2009). As most of these long-lived eddies are anticyclones, it is a suitable region for their study. Our survey of an anticyclonic eddy inside the Canary Eddy Corridor provided for the first time an intensive sampling of one of these long-lived intrathermocline anticyclones. During the interdisciplinary cruise, we carried out near submesoscale 2D sampling as well as mesoscale 3D sampling of the eddy structure. With the data set obtained in the cruise, several works will be published in order to detail the eddy submesoscale structure, ageostrophic secondary circulation, near-inertial wave trapping and physical-biological interactions. The analysis presented here will serve as hydrographic background to the other PUMP studies.

In this study we examined in detail the anatomy of an intrathermocline eddy whose structure is characterized by a biconvex shape of the isopycnals and by a homogeneous layer of subtropical mode water embedded within. Our observations highlight that this structure of an intrathermocline eddy is associated with both a shallow and a deep minimum of PV. The decrease in static stability induced by the biconvex shape of the isopycnals gives rise to the shallower PV minimum located at $85 \mathrm{~m}$ depth. We call this region the eddy dynamical core 


\section{ACCEPTED MANUSCRIPT}

as it is associated with a subsurface maximum in horizontal velocity and also a maximum of absolute relative vorticity. Below this, centered at $225 \mathrm{~m}$ depth, there is a second broad PV minimum generated by the presence of the pycnostad layer composed of subtropical mode water. The occurrence of a subsurface maximum of the velocity field and vertical shear is associated with the biconvex shape of the isopycnals through thermal wind balance.

The eddy studied was $92 \mathrm{~km}$ in diameter and $500 \mathrm{~m}$ in depth, although it was found to influence the hydrographic field down to at least $1000 \mathrm{~m}$. Above the dynamical core, the doming of the seasonal thermocline and pycnocline leads to a narrow cold region in the surface layers introducing a conservative temperature anomaly of $-3{ }^{\circ} \mathrm{C}$. Below the dynamical core, the deepening of the permanent thermocline, halocline and pycnocline leads to a broad, warmer and saltier region located between 200 and $500 \mathrm{~m}$, where the conservative temperature anomaly attains ca. $+2.4{ }^{\circ} \mathrm{C}$. We call this region the eddy hydrographic core. We also observe a relative maximum of $\mathrm{DO}$ in this region and a negative $\mathrm{AOU}$, that may be interpreted as a sign of subduction during the eddy generation process due to the initial deepening of the isopycnals. The eddy has an elliptical shape with signs of shallow filaments at the vertices of the ellipse. It has a central core of $30 \mathrm{~km}$ radius in solid body rotation with a period of ca. 4 days surrounded by a narrow outer ring of $16 \mathrm{~km}$ width that rotates much more slowly. The corresponding Rossby number at the eddy center $(\mathrm{ca}$. Ro $=-0.6)$ is quite high when compared to other subsurface eddies and is reflected in a larger content of KE than APE. The eddy introduces available heat and salt content anomalies of $2.9 \times 10^{18} \mathrm{~J}$ and $14.3 \times$

$10^{10} \mathrm{~kg}$, respectively. These values are larger than those associated with intrathermocline eddies of the California EBUS, and on the same order of magnitude as intrathermocline eddies of the Peru-Chile EBUS.

\section{Acknowledgments}

The authors wish to acknowledge the memory of Dr. Pablo Sangrà who died suddenly following submission of this paper. In addition to a brilliant researcher, he was a beloved teacher by his students and, above all, a good person who also knew how to enjoy life. $\mathrm{He}$ loved the sea and wanted to dedicate his life to understand it and to enjoy it. From the beginning of his research career he was interested in the study of mesoscale processes, especially those originating in the Canary Basin. These studies allowed the identification of the Canary Eddy Corridor (Sangrà et al, 2009). Also, from the first moment, he was interested on participating in multidisciplinary studies to study the physical-biological 


\section{ACCEPTED MANUSCRIPT}

coupling in mesoscale processes. In this sense he was very pleased with the results led by the PUMP project. His death saddens us profoundly.

This work has been carried out as part of PUMP (CTM2012-33355) project funded by the Spanish National Research Program. Bàrbara Barceló-Llull is supported by a pre-doctoral grant from the Spanish National Research Program associated to the PUMP project (BES2013-065459). We express our gratitude to the technical staff (UTM- CSIC) and crew of R/V BIO Hespérides for supporting our work at sea.

\section{References}

1) Allen, J.T., Pollard, R.T., New, A.L., 2012. Ocean Variability \& Acoustic Propagation. Springer Science \& Business Media. chapter How do eddies modify the stratification of the thermocline? pp. 432-448.

2) Arístegui, J., Sangrà, P., Hernández-León, S., Cantón, M., Hernández-Guerra, A., Kerling, J.L., 1994. Island-induced eddies in the Canary Islands. Deep-Sea Res. 49, 1087-1101. doi:10.1016/0967-0637(94)90058-2

3) Barton, E.D., Basterretxea, G., Flament, P., Mitchelson-Jacob, E.G., Jones, B., Arístegui, J., Felix, H., 2000. Lee region of Gran Canaria. Journal of Geophysical Research 105, 17173-17193. doi: 10.1029/2000JC900010

4) Bashmachnikov, I., Neves, F., Calheiros, T. and Carton, X., 2015. Properties and pathways of Mediterranean water eddies in the Atlantic. Progress in Oceanography 137, 149-172. http://dx.doi.org/10.1016/j.pocean.2015.06.001

5) Basterretxea, G., Barton, E. D., Tett, P., Sangrà, P., Navarro-Perez, E., Arístegui, J., 2002. Eddy and deep chlorophyl maximum response to wind-shear in the lee of Gran Canaria. Deep-Sea Research I 49, 1087-1101. doi: 10.1016/S0967-0637(02)00009-2

6) Bretherton, F. P., Davis, R. E., Fandry, C. B. A technique for objective analysis and design of oceanographic experiments applied to MODE-73. Deep Sea Res., 1976, 23, 559-582. doi: 10.1016/0011-7471(76)90001-2

7) Caldeira, R.M.A., Stegner, A., Couvelard, X., Araújo, I.B., Testor, P., Lorenzo, A., 


\section{ACCEPTED MANUSCRIPT}

2014. Evolution of an oceanic anticyclone in the lee of Madeira Island: In situ and remote sensing survey. J. Geophys. Res. Oceans 119. doi:10.1002/2013JC009493

8) Capet, A., Mason, E., Rossi, V., Troupin, C., Faugère, Y., Pujol, I., Pascual, A., 2014. Implications of refined altimetry on es- timates of mesoscale activity and eddy-driven offshore transport in the Eastern Boundary Upwelling Systems. Geophys. Res. Lett. Volume 41, Issue 21, Pages 7602-7610. doi:10.1002/2014GL061770

9) Carnevale, G.F., Kloosterziel, R.C., Orlandi, P., van Sommeren, D.D.J.A., 2011. Predicting the aftermath of vortex breakup in rotating flow. J. Fluid Mech. 669, 90119. doi:10.1017/S0022112010004945

10) Carton, X., Daniault, N., Alves, J., Chérubin, L. and Ambar, I., 2010. Meddy dynamics and interaction with neighboring eddies southwest of Portugal: Observations and modeling. J. Geophys. Res. 115, C06017. doi:10.1029/2009JC005646

11) Carton, X., Le Cann, B., Serpette, A. and Dubert, J., 2013. Interaction of surface and deep anticyclonic eddies in the Bay of Biscay. J. Marine. Syst., 109-110, Supplement S45-S59. doi: http://dx.doi.org/10.1016/j.jmarsys.2011.09.014

12) Chaigneau, A., Le Texier, M., Eldin, G., Grados, C., Pizarro, O., 2011. Vertical structure of mesoscale eddies in the eastern South Pacific Ocean: A composite analysis from altimetry and Argo profiling floats. Journal of Geophysical Research 116. doi:10.1029/2011JC007134

13) Chelton, D.B., deSzoeke, R.A., Schlax, M.A., El Naggar, K., Siwertz, N., 1998. Geographical variability of the first-baroclinic Rossby radius of deformation. J. Phys. Oceanogr. 28, 433-460. doi:10.1175/1520-0485(1998)028<0433:GVOTFB>2.0.CO;2

14) Chelton, D.B., Schlax, M.G., Samelson, R.M., de Szoeke, R.A., 2007. Global observations of large oceanic eddies. Geophys. Res. Lett. 34. doi:10.1029/2007GL030812 


\section{ACCEPTED MANUSCRIPT}

15) Clement, A.C., Gordon, A.L., 1995. The absolute velocity field of Agulhas eddies and the Benguela Current. J. Geophys. Res. 100, 22591-22601.

16) Cushman-Roisin, B., 1986. Frontal geostrophic dynamics. J. Phys. Oceanogr. 16, $132-143$.

17) Dugan, J. P., Mied, R. P., Mignerey, P. C., and Schuetz, A. F., 1982. Compact, intrathermocline eddies in the Sargasso Sea, J. Geophys. Res., 87(C1), 385-393, doi:10.1029/JC087iC01p00385.

18) D'Asaro, E.A., 1988. Observations of small eddies in the Beaufort Sea. J. Geophys. Res. Oceans 93, 6669-6684. doi:10.1029/JC093iC06p06669

19) Feistel, R., 2003. A new extended Gibbs thermodynamic potential of seawater. Progress in Oceanography, 58(1), 43-114. doi:10.1016/S0079-6611(03)00088-0

20) Feistel, R., 2008. A Gibbs function for seawater thermodynamics for -6 to $80^{\circ} \mathrm{C}$ and salinity up to $120 \mathrm{~g} \mathrm{kg-1.} \mathrm{Deep} \mathrm{Sea} \mathrm{Research} \mathrm{Part} \mathrm{I:} \mathrm{Oceanographic} \mathrm{Research} \mathrm{Papers,}$ 55(12), 1639-1671. doi:10.1016/j.dsr.2008.07.004

21) Firing, E., Ranada, J., Caldwell, P., 1995. Processing ADCP data with the CODAS software system version 3.1. Joint Institute for Marine and Atmospheric Research, University of Hawaii \& National Oceanographic Data Center.

22) Flierl, G.R., 1981. Particle motions in large amplitude wave fields. Geophys. Astrophys. Fluid Dyn. 18, 39-74. doi:10.1080/ 03091928108208773.

23) Garcia-Soto, C., Pingree, R.D., Valdés, L., 2002. Navidad development in the southern Bay of Biscay: climate change and swoddy structure from remote sensing and in situ measurements. J. Geophys. Res. 107 (3118). doi:10.1029/2001JC001012

24) Gaube, P., Chelton, D.B., Samelson, R.M., Schlax, M.G., O’neill, L.W., 2015. Satellite Observations of Mesoscale Eddy-Induced Ekman Pumping. J. Phys. Oceanogr. 
25) Gordon, A.L., Giulivi, C.F., Lee, C.M., Furey, H.H., Bower, A., Talley, L., 2002. Japan/East Sea Intrathermocline Eddies. J. Phys. Oceanogr. 32, 1960-1974.

26) Hanawa, K., Talley, L.D., 2001. Ocean Circulation and Climate. Academic Press. chapter Mode Waters. pp. 373-386.

27) Hansen, C., Kvaleberg, E., Samuelsen, A., 2010. Anticyclonic eddies in the Norwegian Sea; their generation, evolution and impact on primary production. DeepSea Res. 57, 1079-1091. doi:doi:10.1016/j.dsr.2010.05.013

28) Hebert, D., 1988. The Available Potential Energy of An Isolated Feature. J. Geophys. Res. 93, 556-564.

29) Hebert, D., Oakey, N., Ruddick, B., 1990. Evolution of a Mediterranean Salt Lens: Scalar Properties. J. Phys. Oceanogr. 20, 1468-1483.

30) Hogan, P.J., Hurlburt, H.E., 2006. Why do IntraThermocline Eddies Form in the Japan/East Sea? A Modeling Perspective. Oceanography 19, 134-143. URL: http://dx.doi.org/10.5670/oceanog.2006.50

31) Hormazabal, S., Combes, V., Morales, C.E., Correa-Ramirez, M.A., Di Lorenzo, E., Nuñez, S., 2013. Intrathermocline eddies in the coastal transition zone off central chile (31-41 ${ }^{\circ}$ S). J. Geophys. Res. 118, 1-11. doi:10.1002/jgrc.20337

32) Jiménez, B., Sangrà, P., Mason, E., 2008. A numerical study of the relative importance of wind and topographic forcing on oceanic eddy shedding by tall, deep water islands. Ocean Modell. 22, 146-157. doi:10.1016/j.ocemod.2008.02.004

33) Käse, R. H., W. Zenk, T. B. Sanford, and W. Hiller, 1985. Currents, fronts and eddy fluxes in the Canary Basin. Progress in Oceanography, Vol. 14, Pergamon, 231-257.

34) Klein, P. and Lapeyre, G., 2009: The oceanic vertical pump induced by mesoscale eddies, Annu. Rev. Mar. Sci., 1, 351-375, 2009. 
35) Kloosterziel, R.C., van Heijst, G.J.F., 1991. An experimental study of unstable barotropic vortices in a rotating fluid. Journal of Fluid Mechanics, 223, 1-24. doi: http://dx.doi.org/10.1017/S0022112091001301.

36) Kostianoy, A. G. and Belkin, I. M., 1989. A Survey of Observations on Intrathermocline Eddies in the World Ocean. Elsevier Oceanography Series, 50, 821841. doi: https://doi.org/10.1016/S0422-9894(08)70223-X

37) Le Traon, P.-Y., 1990. A method for optimal analysis of fields with spatially-variable mean. J. Geophys. Res., 95, 13543-13547. doi: 10.1029/JC095iC08p13543

38) L’Hégaret, P., Carton, X., Ambar, I., Ménesguen, C., Lien Hua, B., Chérubin, L., Aguiar, A., Le Cann, B., Daniault, N. And Serra, N., 2014. Evidence of Mediterranean Water dipole collision in the Gulf of Cadiz. J. Geophys. Res. Oceans, 119, 5337-5359. doi: 10.1002/ 2014JC009972

39) Mahadevan, A.; Thomas, L. N.; Tandon, A., 2008. Comment on "Eddy/Wind Interactions Stimulate Extraordinary Mid-Ocean Plankton Blooms" Science, 320. doi: $10.1126 /$ science. 1152111

40) Martin, A.P., Richards, K.J., 2001. Mechanisms for vertical nutrient transport within a North Atlantic mesoscale eddy. Deep-Sea Research Part II: Topical Studies in Oceanography $48,757-773$.

41) Mc Clain, C.R., Esaias, W.E., Barnes, W., Guenther, B., Endres, D., Hooker, S.B., Mitchell, B.G., Barnes, R., 1996. SeaWiFS calibration and validation quality control procedures. NASA Tech. Memo. 104566, vol. 38, SeaWiFS Tech. Report Series, 64 p.

42) McGillicuddy, D.J., 2015. Formation of Intrathermocline Lenses by Eddy Wind Interaction. J. Phys. Oceanogr. 45, 606-612. doi:10.1175/JPO-D-14-0221.1

43) McGillicuddy, D. J., 2016. Mechanisms of Physical-Biological-Biogeochemical 


\section{ACCEPTED MANUSCRIPT}

Interaction at the Oceanic Mesoscale. Annual Review of Marine Science, 8, 125-159. doi: 10.1146/annurev-marine-010814-015606

44) McGillicuddy, D.J., Anderson, L.A., Bates, N.R., Bibby, T., Buesseler, K.O., Carlson, C.A., Davis, C.S., Ewart, C., Falkowski, P.G., Goldthwait, S.A., Hansell, D.A., Jenkins, W.J., Johnson, R., Kosnyrev, V.K., Ledwell, J.R., Li, Q.P., Siegel, D.A., Steinberg, D.K., 2007. Eddy Wind interactions stimulate extraordinary mid-ocean plankton blooms. Science 316, 1021-1026.

45) McWilliams, J. C., 1985. Submesoscale, coherent vortices in the ocean. Rev. Geophys., 23 (2), 165-182. doi: 10.1029/RG023i002p00165

46) Nauw, J.J., van Aken, H.M., Lutjeharms, J.R.E., de Ruijter, W.P.M., 2006. Intrathermocline eddies in the Southern Indian Ocean. J. Geophys. Res. 111. doi:10.1029/2005JC002917

47) Nencioli, F., Kuwahara, V.S., Dickey, T.D., Rii, Y.M., Bidigar, R.R., 2008. Physical dynamics and biological implications of a mesoscale eddy in the lee of Hawai'i: Cyclone Opal observations during E-Flux III. Deep-Sea Res. 55, 1252-1274. doi:10.1016/j.dsr2.2008.02.003

48) Oka, E., 2009. Seasonal and Interannual Variation of North Pacific Sub- tropical Mode Water in 2003-2006. Journal of Oceanography 65, 151-164.

49) Olson, D.B., 1980. The Physical Oceanography of Two Rings Observed by the Cyclonic Ring Experiment. Part II: Dynamics. J. Phys. Oceanogr. 10, 514-528. doi:http://dx.doi.org/10.1175/1520-0485(1980)010<0514:TPOOTR>2.0.CO;2

50) Olson, D.B., Schmitt, R.W., Kennelly, M., Joyce, T.M., 1985. A two-layer diagnostic model of the long-term physical evolution of warm-core ring 82B. J. Geophys. Res. Oceans 90, 8813-8822. doi:10.1029/JC090iC05p08813

51) Ou, H.W., Gordon, A., 2002. Subduction along a midocean front and the generation 


\section{ACCEPTED MANUSCRIPT}

of intrathermohaline eddies: a theoretical study. J. Phys. Oceanogr. 32 (6), 19751986.

52) Pegliasco, C., Chaigneau, A., Morrow, R., 2015. Main eddy vertical structures observed in the four major Eastern Boundary Upwelling Systems. J. Geophys. Res. 120, 6008-6033. doi:10.1002/2015JC010950

53) Pelland, N.A., Eriksen, C.C., Lee, C.M., 2013. Subthermocline Eddies over the Washington Continental Slope as Observed by Seagliders, 2003-09. J. Phys. Oceanogr. 43, 2025-2053. doi:10.1175/JPO-D-12-086.1

54) Pidcock, R., Martin, A., Allen, J., Painter, S.C., Smeed, D., 2013. The spatial variability of vertical velocity in an iceland basin eddy dipole. Deep-Sea Res. 72, $121-140$.

55) Piedeleu, M., Sangrà, P., Sánchez-Vidal, A., Fabrés, J., Gordo, C., Calafat, A., 2009. An observational study of oceanic eddy generation mechanisms by tall deep-water islands (Gran Canaria). Geophys. Res. Lett. 36. doi:10.1029/2008GL037010

56) Pingree, R.D., 1996. A Shallow Subtropical Subducting Westward Propagating Eddy (Swesty). Philosophical Transactions: Mathematical, Physical and Engineering Sciences 354, 979-1026.

57) Pingree, R. D. and Le Cann, B., 1992a. Three anticyclonic Slope Water Oceanic eDDIES (SWODDIES) in the Southern Bay of Biscay in 1990. Deep-Sea Res. 39, 78, 1147-1175. doi: http://dx.doi.org/10.1016/0198-0149(92)90062-X

58) Pingree, R. D. and Le Cann, B., 1992b. Anticyclonic Eddy X91 in the Southern Bay of Biscay, May 1991 to February 1992. J. Geophys. Res. 97 (C9), 14353-14367. doi: 10.1029/92JC01181

59) Prater, M.D., Sanford, T.B., 1994. A Meddy off Cape St. Vincent. Part I: Description. J. Phys. Oceanogr. 24, 1572-1586. 
60) Rudnick, D.L., 1996. Intensive surveys of the Azores Front: 2. Inferring the geostrophic and vertical velocity fields. J. Geophys. Res. Oceans 101, 16291-16303. doi:10.1029/96JC01144

61) Sánchez, R. and Gil, J., 2004. 3D structure, mesoscale interactions and potential vorticity conservation in a swoddy in the Bay of Biscay. J. Marine Systems 46, 47-68. doi:10.1016/j.jmarsys.2003.10.002

62) Sangrà, P., Auladell, M., Marrero-Díaz, A., Pelegrí, J.L., Fraile-Nuez, E., RodríguezSantana, A., Martín, J.M., Mason, E., Hernández-Guerra, A., 2007. On the nature of oceanic eddies shed by the island of Gran Canaria. Deep-Sea Res. 54, 687-709. doi:10.1016/j.dsr.2007.02.004

63) Sangrà, P., Pascual, A., Rodríguez-Santana, A., Machín, F., Mason, E., McWilliams, J.C., Pelegrí, J.L., Dong, C., Rubio, A., Arístegui, J., Marrero-Díaz, A., HernándezGuerra, A., Martínez-Marrero, A., Auladell, M., 2009. The Canary Eddy Corridor: a major pathway for long-lived eddies in the subtropical North Atlantic. Deep-Sea Res. 56, 2100-2114. doi:10.1016/j.dsr.2009.08.008

64) Sangrà, P., Pelegrí, J.L., Hernández-Guerra, A., Arregui, I., Martín, J.M., MarreroDíaz, A., Martínez, A., Ratsimandresy, A.W., Rodríguez-Santana, A., 2005. Life history of an anti-cyclonic eddy. J. Geophys. Res. 110. doi:10.1029/2004JC002526

65) Sato, O.T., Polito, P.S., 2014. Observation of South Atlantic subtropical mode waters with Argo profiling float data. J. Geophys. Res. Oceans 119, 2860-2881. doi:10.1002/ 2013JC009438

66) Shapiro, G.I., Zenk, W., Meschanov, S.L. and Schultz Tokos, K.L., 1995. Selfsimilarity of the meddy family in the Eastern North Atlantic. Oceanologica Acta 18(1), 29-42. http://archimer.ifremer.fr/doc/00097/20779/

67) Siedler, G., A. Kuhl, and W. Zenk, 1987. The Madeira Mode Water. J. Phys. Oceanogr., 17, 1561-1570. 


\section{ACCEPTED MANUSCRIPT}

68) Schmid, C., Schäfer, H., Zenk, W., Podestá, G., 1995. The Vitória Eddy and Its Relation to the Brazil Current. J. Phys. Oceanogr. 25, 2532-2546. doi:http://dx.doi.org/10.1175/1520-0485(1995)025<2532:TVEAIR>2.0.CO;2

69) Schultz Tokos, K., Rossby, T., 1991. Kinematics and dynamics of a mediterranean salt lens. J. Phys. Oceanogr. 21, 879-892. doi:http://dx.doi.org/10.1175/15200485(1991)021<0879:KADOAM>2.0.CO;2

70) Schütte, F., Brandt, P., Karstensen, J., 2015. Occurrence and characteristics of mesoscale eddies in the tropical northeast Atlantic Ocean. Ocean Sci. Discuss. 12, 3043-3097. doi:10.5194/osd-12-3043-2015

71) Stramma, L., Bange, H.W., Czeschel, R., Lorenzo, A., Frank, M., 2013. On the role of mesoscale eddies for the biological productivity and biogeochemistry in the eastern tropical Pacific Ocean off Peru. Biogeosciences 10, 7293-7306. doi:10.5194/bg-107293-2013

72) Thomas, L.N., 2008. Formation of intrathermocline eddies at ocean fronts by winddriven destruction of potential vorticity. Dynam. Atmos. Oceans 45, 252-273. doi:10.1016/j.dynatmoce.2008.02.002

73) Viúdez, A., Dritschel, D.G., 2003. Vertical velocity in mesoscale geophysical flows. J. Fluid Mech. 483, 199-223. doi:10.1017/S0022112003004191

74) Xu, L., Li, P.; Xie, S, Liu, Q., Liu, C., Gao, W, 2016. Observing mesoscale eddy effects on mode-water subduction and transport in the North Pacific. Nature Comunication, 7:10505, DOI: 10.1038/ncomms10505

75) Weller, R. A., P. W. Furey, M. A. Spall, and R. E. Davis, 2004. The large-scale context for oceanic subduction in the Northeast Atlantic. Deep-Sea Res., 51A, 665699. 